\title{
Neotectonic movements and their geomorphic response as reflected in surface parameters and stress patterns in the Eastern Alps
}

\author{
B. Székely ${ }^{*}$, J. Reinecker ${ }^{\dagger}$, I. Dunkl ${ }^{\dagger \dagger}$, W. Frisch , and J. Kuhlemann \\ Institut für Geowissenschaften, Universität Tübingen, Tübingen, Germany \\ *Also at Space Research Group, Department of Geophysics, Eötvös University, Budapest, Hungary \\ ${ }^{\dagger}$ Now at Geophysical Institute, University of Karlsruhe, Karlsruhe, Germany \\ ${ }^{\dagger}$ Also at Laboratory for Geochemical Research, Hungarian Academy of Sciences, Budapest, Hungary
}

Received: 2 May 2000 - Accepted: 9 November 2001

\begin{abstract}
Present-day tectonics of the Eastern Alps are characterized by strike-slip faulting regime in a complex transition zone between the European, the Pannonian and the Adriatic stress provinces. Evidence can be found for vertical as well as horizontal stress decoupling within the orogen due to a thermally and mechanically weakened crust. Differential vertical uplift derived from repeated precise levellings relative to the reference point in the Bohemian massif is observed in western Austria including the Tauern Window and subsidence in the Vienna basin and in the Styrian basin. We relate this behaviour of vertical motions to the effects of isostatic response to active plate convergence and strain partitioning as well as to rebound in response to Quaternary deglaciation and ice-induced erosion.

Statistical methods of surface evaluation have been applied on the Digital Elevation Model (DEM) to characterize the major domains of tectono-geomorphic units. A remarkable correlation between surface ruggedness and denudation history can be established by combining the DEM-derivatives and fission track data. The domains delineated by low fourth order DEM-derivative values fairly depict areas having paleosurface remnants, while regions characterized by high parameter values typically are areas with high denudation rates in Miocene to Recent time. However, the areas affected by Pleistocene glaciation have specific behaviour.
\end{abstract}

\section{Introduction}

\subsection{Scope and goals}

Several studies have focused on the neotectonic behaviour of the Eastern Alps in the last decade. A number of models have been proposed to explain recognized features like large-scale strike-slip faulting, ongoing uplift and denudational processes (Grundmann and Morteani, 1985; Staufen-

Correspondence to: B. Székely

(balazs.szekely@uni-tuebingen.de) berg 1987; Dunkl and Demény, 1997; Hejl, 1997; Dunkl et al., 1998; Frisch et al., 1998; Reinecker and Lenhardt, 1999).

The present topography of the Eastern Alps is characterized by a general west-to-east decrease in mean and maximum elevations (Frisch et al., 1998). The drainage pattern is dominated by $\mathrm{E}-\mathrm{W}$ longitudinal valleys with the main rivers having typically eastward drainage direction. Most of these valleys are tectonically determined in the mode of strike-slip faulting. Some of the valleys are found to be seismically active: this activity suggests that strike-slip faulting is an ongoing process; most of these tectonic lines have particularly been active in Miocene times, when the large-scale strikeslip faulting reshaped the previously N-S directed drainage pattern (Frisch et al., 1998).

Precise levellings outline domains that have suffered measurable vertical motion within a couple of decades. The stress pattern is complex in the study area, and the region was interpreted as a sort of decoupling zone between established stress provinces (Reinecker and Lenhardt, 1999; Reinecker, 2000).

The aim of this paper is to describe the geomorphic response of these processes by relating the surface parameters to the stress pattern data:

(1) The present-day tectonic processes are reflected in horizontal and vertical motions. We try to interpret the vertical motion pattern based on precise levelling data; the horizontal motions may be inferred from the fault plane solutions of recent seismic events showing strikeslip deformation. These data are compared to the stress pattern (Reinecker and Lenhardt, 1999).

(2) An attempt is made here to combine several databases to characterize the presently active endogenous processes which determined the neotectonic situation and the morphological evolution of the area. The geomorphic features of the region are evaluated by applying statistical methods on the Digital Elevation Model (DEM) in combination with denudation rates derived from fission track data. 
(3) Characteristics of the actual surface are consequences of both short- and long-term denudation processes. The observed stress pattern, uplift and seismicity patterns allow inferences for the short-term behaviour of the tectonic units: we test the hypothesis whether the shortterm behaviour is coupled with long-term lateral and vertical motions and crustal scale structures.

\subsection{Previous tectono-geomorphic concepts}

In spite of the exponential increase in computer power and the availability of relatively good resolution DEM data, there have been only partial proceedings in the geological DEM evaluation of the Eastern Alps. Guzzetti and Reichenbach (1994) presented a topographic division of Italy including its Alpine part, but the area was separated into only two regions (Western Alps and Central-Eastern Alps), which formed a mixture of tectonic units; thus, this separation is not suitable for detailed geological studies. Other geomorphic studies were based on field observations and used classic methods. These studies usually focused on geological processes as they are reflected in the geomorphic pattern: planation surfaces and peak levels were evaluated to characterize the uplift stages and rate (Winkler-Hermaden, 1957; Sakaguchi, 1973; Dongus, 1984). Frisch et al. (1998) used the average topographic height of tectonic units to demonstrate the eastward decrease of topography which has been related to Miocene lateral tectonic extrusion (Ratschbacher et al., 1991a). One of the first attempts of geomorphic domain segmentation related to tectonic units in the Eastern Alps was made by Frisch et al. (2000b); their study combined DEM-evaluation results with geological field evidence.

In this paper we continue this work by using both known and developed techniques of image processing: several derivatives of the DEM are presented to numerically characterize the tectonic units from the geomorphic point of view.

\section{Data and their errors}

\subsection{The data}

The used DEM data set had a medium resolution with $100 \mathrm{~m}$ pixel size and a vertical resolution of $16 \mathrm{~m}$. Although this data set is obviously not well-suited for detailed studies, it was found to be satisfying for our purposes: delineating general trends and outlining some major patterns.

Statistic parameters have been computed and standard image processing techniques have been applied to the raw data set: slope angle calculation, histogram analysis, supervised and unsupervised classification and filtering (using ranking, enhancement and averaging filters) were carried out. These methods are described in more details in Székely (2001).

The stress data, seismicity and results of precise levellings used here have been collected by Reinecker (2000). The glaciation data used to relate the isostatic rebound of the deglaciation to the observed uplift is taken from the classic map of van Husen (1987). Although there are some concerns about the accuracy of this data set in some parts (see Florineth and Schlüchter, 1998), we have chosen this data set because of its homogeneity. Neogene exhumation was computed from a compilation of published and unpublished fission track data (Staufenberg, 1987; Hejl and Wagner, 1989; Fügenschuh et al., 1997; Hejl, 1997; Dunkl et al., 1998; Elias, 1998; Sachsenhofer et al., 1998; Stöckhert et al., 1999; Reinecker, 2000; and Dunkl (unpublished)).

\subsection{Error sources}

To have a realistic overview of the data, it is important to provide a short assessment of the possible error sources of the various data sets which our inferences are based on.

The accuracy of seismicity data is usually determined by the station density, the depth of foci and the level of seismicity in the region. Since all detected earthquakes are found to have shallow foci $(\leq 10 \mathrm{~km})$ the depth determinations have typically high errors. The horizontal positions are expected to be accurate, but the events appropriate for focal mechanism determination are rare, and frequently result in lower quality (C) solutions due to the poor station geometry. Despite the low number of fault plane solutions, they exhibit a coherent pattern (Reinecker and Lenhardt, 1999) and remarkable similarity to that of the VLBI- and GPS-based results.

The determination of vertical movements by repeated precise levelling has a considerable error by the nature of the measurements. Although the computed errors are expected to decrease in time, the time passed between the surveys is not enough to decrease the errors dramatically. The lower the absolute value of the vertical movement, the higher the error; $0.2-0.3 \mathrm{~mm} / \mathrm{a}$ is a good estimate for a typical value (BEV, 1991). Thus, uplift or subsidence values above $1 \mathrm{~mm} / \mathrm{a}$ (in relative sense) should be treated as significant.

Although the theoretical background of the rheological calculations is well established, the low accuracy or lack of input data frequently prevents the experimenter to calculate rheological profiles with low ambiguity. On the other hand, rheological contrast between the Tauern Window, a textbook example of weak rheology, (Genser et al., 1996) and the surrounding tectonic blocks with high yield strength supports the assumption of their different rheological behaviour.

As it was stated above the DEM data used in this study is not well suited for detailed studies. The relatively high quantization error in vertical sense and the $100 \mathrm{~m}$ horizontal resolution implies problems with local accuracy and, especially, underestimated slope angles. The latter affects mainly the steeper slopes, therefore in the more rugged areas the percentage of steep slopes is also underestimated. Since the contrast between the rough and smooth areas found to be enough to separate these domains by applying a classification technique, we expect that more accurate data would enhance these differences.

Although there are new results updating the classic map of van Husen (1987), here only the outline of the conterminous LGM ice body are used. This boundary is expected to be 


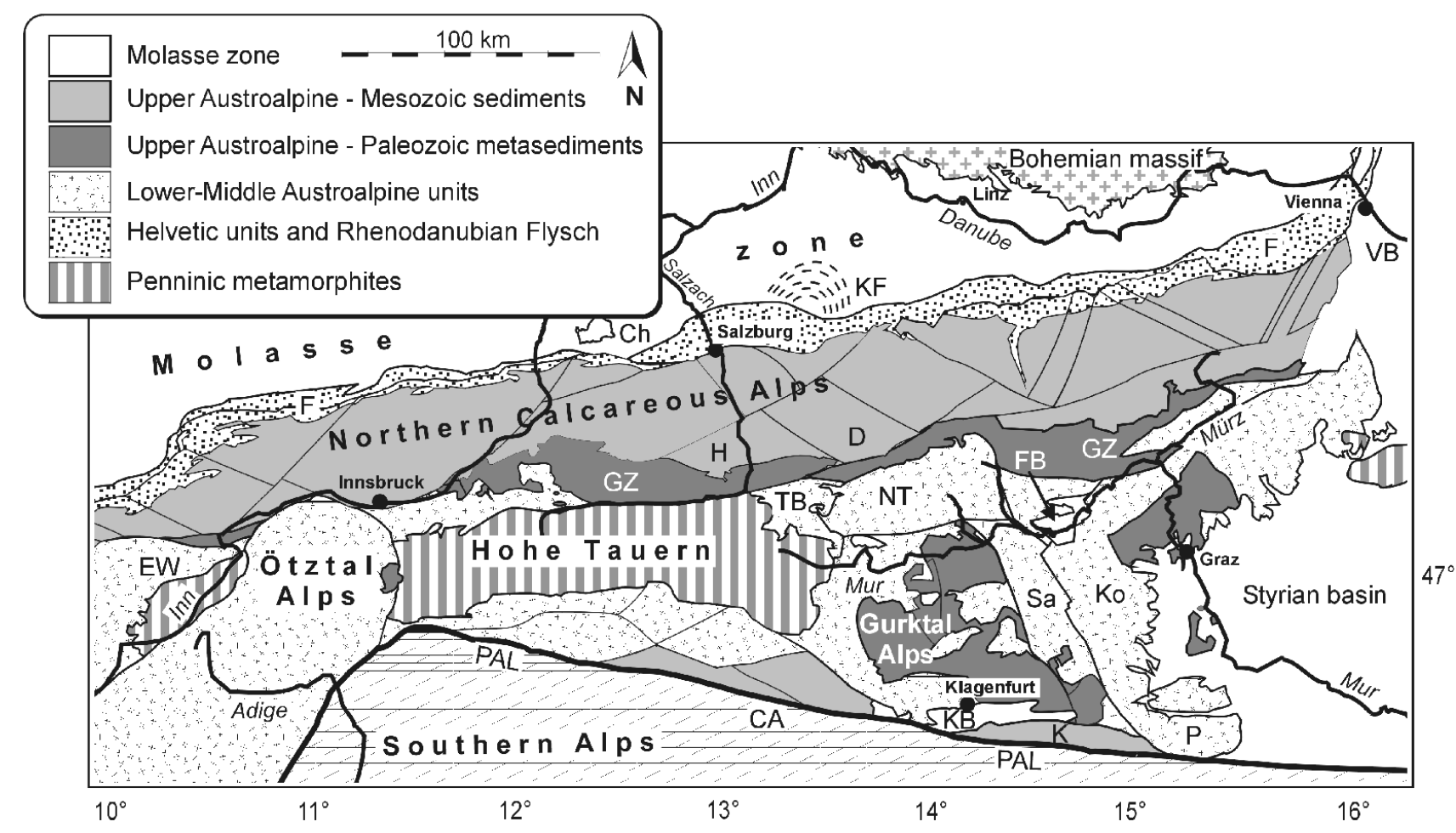

Fig. 1. Major tectonic units of the study area and localities mentioned in the text. CA: Carnic Alps, Ch: Chiemsee, D: Dachstein, EW: Engadine Window, F: Flysch zone, FB: Fohnsdorf basin, GZ: Greywacke zone, H: Hochkönig, K: Karawanks, KB: Klagenfurt basin, KF: Kobernausser fan, Ko: Koralpe, NT: Niedere Tauern, P: Pohorje, PAL: Periadriatic Lineament, Sa: Saualpe, TB: Tamsweg basin, VB: Vienna basin.

more accurate than the ice surface elevation data because of the widespread trimline observations.

Concerning the fission track data there are a lot of uncertainties coming from the nature of the method itself, from the measurement technique, from the problem in defining the closure temperature, from the conversion of ages to exhumation thicknesses, etc. In this paper we have created categories of exhumation thicknesses and this way we expect to avoid these problems. In most of the cases the boundaries between categories represent tectonics lines; in some other cases transitional boundaries are drawn, where continuous transition is expected (see below).

\section{Neotectonic movements and lithospheric structure}

\subsection{Active faulting}

Seismicity is concentrated in narrow zones, which generally correlate with mapped fault zones inherited from the Miocene lateral tectonic extrusion pattern.

In eastern Austria the highest seismic activity is found along a zone reaching from the southern Vienna basin to the Mur-Mürz valley. (For tectonic units and localities see Fig. 1.) Fault plane solutions from shallow foci $(<9 \mathrm{~km}$ depth) along this zone mainly exhibit sinistral strike-slip movements (Fig. 2). However, three earthquakes with fo- cal depth $>10 \mathrm{~km}$ indicate opposite kinematics. According to published profiles (Aric, 1981; Wessely, 1987; Zimmer and Wessely, 1996), these foci seem to be located within the Bohemian crystalline basement. In the lack of further fault plane solutions (cf. Reinecker and Lenhardt, 1999) we conclude that kinematic behaviour between the upper plate (the Austroalpine nappe stack) and the lower plate (the Bohemian massif as a part of the European plate) is fundamentally different. Stress decoupling probably occurs in a zone of weak, schistose lithologies of the Penninic unit sandwiched between the Bohemian massif and the Austroalpine nappe stack.

Along the Mur-Mürz fault zone, an average rate of $0.3 \mathrm{~mm} / \mathrm{a}$ of sinistral strike-slip movement was calculated from earthquake data (Aric, 1981). Aseismic deformation is not considered in this figure.

Another distinct seismically active zone is the northern part of the NNW-SSE trending Lavanttal fault with clear dextral strike-slip kinematics (Fig. 2). In the wedge between these two faults, a tectonic escape block is inferred to perform eastward motion relative to the Gurktal block further west. Within the Gurktal block two seismic events indicate different kinematics. According to the ALP-75 profile (Aric, 1981), the focal depths of these events (10 and $13 \mathrm{~km})$ fall within the Penninic substratum of the Austroalpine basement lid.

In the Southern Alps, the Friuli region experiences high 


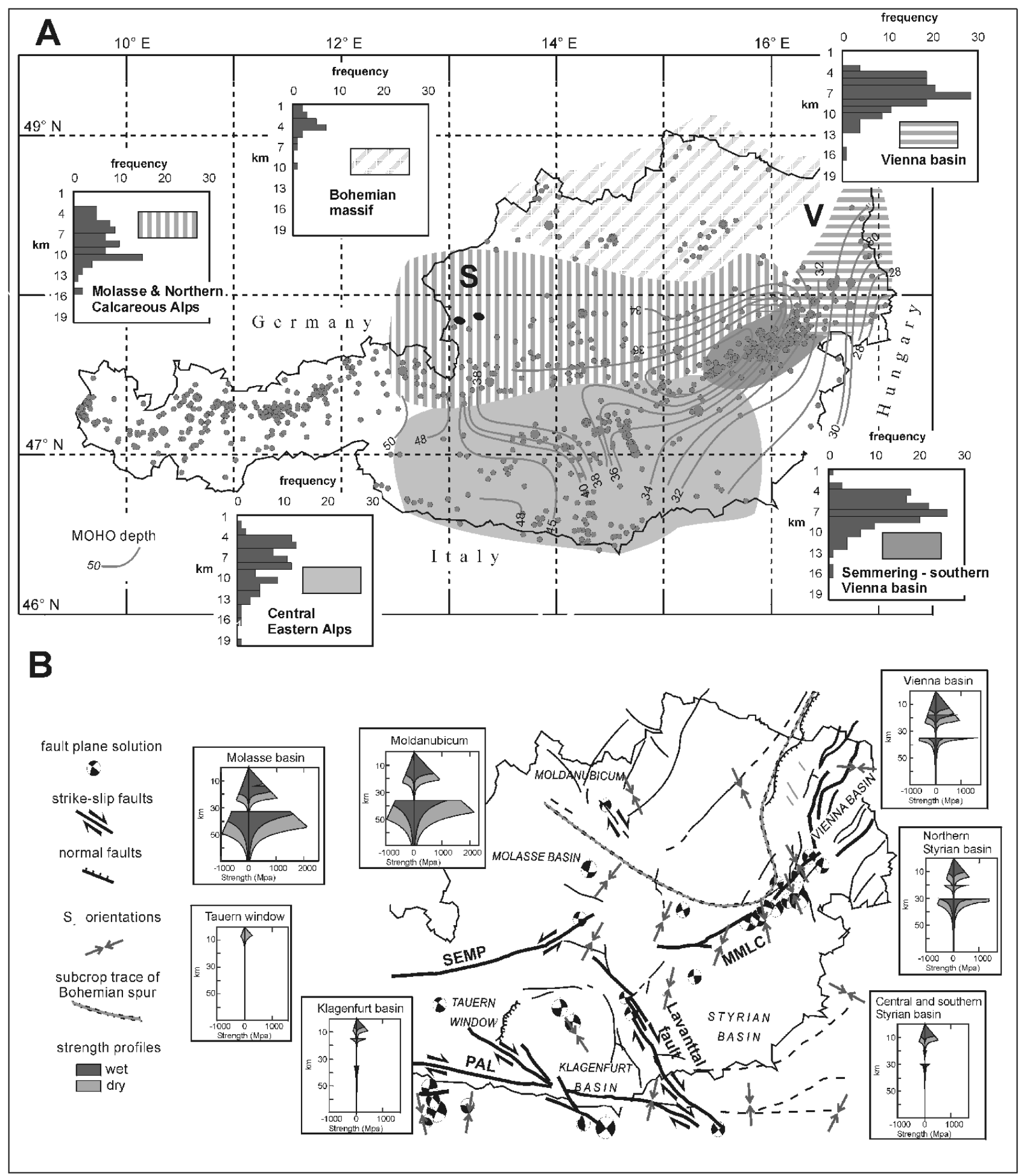

Fig. 2. (A) Seismic activity in Austria 1900-1998 (ZAMG, 1999) and its relationship to the crustal thickness (Posgay et al., 1991). Bar charts display the depth distribution of earthquake activity of the areas drawn with different shading. S: Salzburg; V: Vienna. (B) Fault plane solutions, major strike-slip faults, $\mathrm{S}_{\mathrm{H}}$-orientations (Reinecker and Lenhardt, 1999) and rheological properties (Genser et al., 1996; Nemes et al., 1997; Sachsenhofer et al., 1997; Lankreijer, 1998; see also Reinecker, 2000) in Eastern Austria. SEMP: Salzachtal-Ennstal-MariazellPuchberg line; PAL: Periadriatic Lineament; MMLC: Mur-Mürz-Leitha-Little Carpathian fault system. 


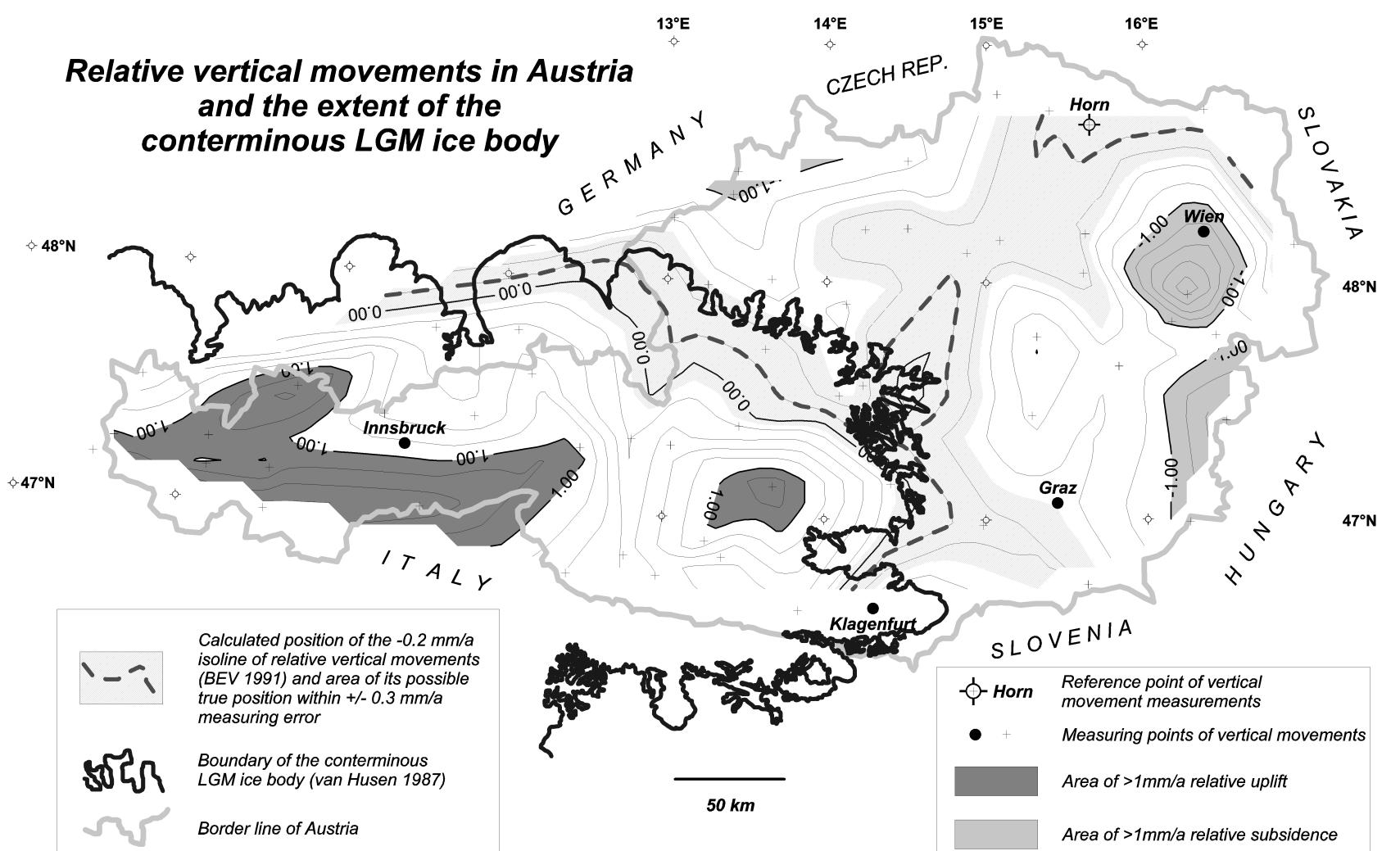

Fig. 3. Vertical movement rates in mm/a relative to Horn (Bohemian massif) derived from precise levelling data in Austria (data from BEV (1991)) and the extent of the conterminous LGM ice body (van Husen 1987). The calculated errors for the vertical movements range between $0.2-0.5 \mathrm{~mm} / \mathrm{a}$. Three major provinces can be distinguished: a relatively uplifting area in and around the Tauern Window, a relatively subsiding region in the Vienna basin and the Pannonian (Styrian) basin, and a more or less neutral zone in-between. The boundary of the LGM ice body fairly correlates with the $-0.2 \mathrm{~mm} / \mathrm{a}$ contour line if we take into account the typical measuring error value of $\pm 0.3 \mathrm{~mm} / \mathrm{a}$.

seismicity with magnitudes up to 6.5. Kinematics are strikeslip faulting in the eastern part and thrust faulting in the western and central parts of this region (Bressan et al., 1998). Thrust faulting is top-to-the-south, indicating backthrusting of the Alpine body toward the Po foreland.

Earthquakes in the Pannonian basin exhibit predominantly strike-slip and thrust fault regimes. Normal faulting events are not observed (Müller et al., 1992; Gerner et al., 1995). Horváth and Cloetingh (1996) propose that the relatively weak mantle lithosphere leads to a concentration of stress in the upper $15 \mathrm{~km}$ of the lithosphere, which is in accordance with the absence of seismicity below $15-20 \mathrm{~km}$.

\subsection{Vertical movements}

Repeated precise levellings show vertical movement trends relative to the locality Horn in the Bohemian massif (BEV, 1991; Fig. 3). The overall vertical movement pattern shows that there is a strongly uplifting part with rates exceeding $1 \mathrm{~mm} / \mathrm{a}$ (relative to Horn) along the main crest of the Eastern Alps in the Tauern window and further west. This area coincides with crustal thickness exceeding about $45 \mathrm{~km}$ (e.g. Giese (1980), negative Bouguer anomalies exceeding values of $-140 \mathrm{mGal}$ (Giese, 1980), and negative isostatic anomalies (Meurers, 1992). This is in contrasts with the area east and northeast of the Tauern window, showing predominantly relative subsidence, with rates up to $-1 \mathrm{~mm} / \mathrm{a}$. This area is characterized by steep gradients of eastward decreasing crustal thickness and eastward decreasing negative Bouguer gravity, respectively neutral to positive isostatic gravity values. The Molasse foreland shows similar subsidence values relative to Horn. The erosional history of the Molasse zone and water gaps of the Danube river incising some $250 \mathrm{~m}$ into the Bohemian massif, however, suggest that this part may in fact be slowly uplifting. The youngest preserved molasse sediments in Kobernausser fan have an age of 8 Ma (Mackenbach, 1984). The eroded thickness of fluvial gravel in this fan exceeds $200-300 \mathrm{~m}$ (estimated from maturity of coal below the gravel beds, Sachsenhofer, pers. comm.). Thus, the overall incision of the Danube in the past 5(8) Ma may have been in the order of 700-800 m (top of Kobernausser fan minus base level of Danube projected to a comparable upstream point) yielding an average uplift rate in the order of $0.1 \mathrm{~mm} / \mathrm{a}$. According to these considerations, the eastern part of the Eastern Alps would also rather be approximately neutral with respect to uplift instead of a zone of subsidence.

Besides the general trend the repeated precise levellings indicate differential uplift in local sense, too. Detected sharp vertical movement discontinuities across mapped shear faults 
are interpreted as vertical movement component along these faults. In most instances, however, no decision can be made between disjunctive movement along a fault and continuous flexural bending. A clear case of disjunctive movement occurs along the westernmost Mur-Mürztal fault system (Fig. 2; Reinecker, 2000). The northern block shows significant uplift with a rate in the order of $1 \mathrm{~mm} /$ a relative to the southern block. In two places further east, levellings across the Murtal (Mur valley) fault reveal subsidence of the northern block relative to the southern block in the order of $0.5 \mathrm{~mm} / \mathrm{a}$ (Reinecker, 2000).

A strong relative subsidence value in the Klagenfurt basin (locality Klagenfurt) indicates loading by ongoing thrusting of the Karawanken mountains to the north onto the Neogene filling of the basin. Quaternary faulting is proven by open fissures in Pleistocene pebbles (van Husen, 1976) and recent thrusting is presumable from VLBI measurements (Ward, 1994).

Although no earthquakes related to normal faulting are observed in the Vienna basin, subsidence is evident from precise levellings, the Mitterndorf graben structure fill with Quaternary deposits (e.g. Tollmann, 1986), and geomorphic field observations (Decker and Peresson, 1998). Although part of the actual subsidence may be due to hydrocarbon exploitation, the Mitterndorf graben in particular shows that extensional tectonics including normal faulting was active in Quaternary times. In several places, levelling lines across the Vienna basin suggest disjunctive vertical motion with internal parts of the basin subsiding due to normal faulting (Höggerl, 1980, 1993; Kröll et al., 1993).

Subsidence in the Vienna basin has been related to a pullapart mechanism with 1.5 to $2 \mathrm{~km}$ sinistral slip during the Quaternary (Decker and Peresson, 1998).

\subsection{Rheology of the lithosphere}

Rheological profiles have been modelled for various sites of the Eastern Alps and adjacent areas (Fig. 2b; Genser et al., 1996; Nemes et al., 1997; Sachsenhofer et al., 1997; Lankreijer, 1998). Striking features are the strong Bohemian and the weak Pannonian lithosphere (Lankreijer, 1998). Genser et al. (1996) modelled a very weak lithosphere in the Tauern window. Only the upper crustal layer shows limited strength. In particular, the weak lithospheric mantle beneath the Tauern window is in sharp contrast to the strong lithospheric mantle north and south of the orogen.

The Styrian basin shows relatively strong upper and middle but weak lower crust. The strength of the lithospheric mantle contrasts between the northern and the central to southern part of the basin (Sachsenhofer et al., 1997). The weak lithospheric mantle of the central and southern Styrian basin is related to high heat flow by the same authors. Assuming a crustal thickness of between 40 and $45 \mathrm{~km}$ and elevated heat flow in the Klagenfurt basin, Nemes et al. (1997) found distinct decoupling of upper and middle crust, and generally low strengths for the lower crust and lithospheric mantle.
The modellings show that the Eastern Alps contain a weak internal part in the Tauern window, but outside the window, the lower crust and upper mantle also appear to have generally low strengths. This situation partly continues into the western Pannonian (Styrian) lithosphere. The resulting deformation is rather diffuse. The stronger lithosphere parts to the north (Bohemian massif) and to the south (Adriatic indenter) stimulate deformation in the Eastern Alps, which concentrates along discrete fault zones in the strong upper parts of the crust. In greater depth the deformation becomes more diffuse and is no more recorded by earthquakes. Stress patterns in the areas surrounding the Eastern Alps display three stress provinces with different orientations of maximum horizontal compressional stress (Fig. 2b): the European province (to which the Bohemian massif belongs), the Pannonian province, and the Adriatic province (Reinecker, 2000). Stress data in the eastern part of the Eastern Alps clearly show that this zone is characterized by decoupling between these stress provinces. This is due to the weak behaviour of the lithosphere and also to the segmentation of the upper crustal layer (Austroalpine basement, generally $<10 \mathrm{~km}$ deep), which floats on weak Penninic schistose lithologies.

\section{Characterization of the surface ruggedness pattern}

\subsection{Methodical considerations}

Stress data, seismicity and uplift rate estimations are classic parameters for geomorphic studies. The geologic-geomorphic observations on planation surfaces and relief allowed inferences for uplift and history (tectonic activity/quiescence).

A number of models have been proposed and tested in various areas of the world with different tectonic settings to have in-depth knowledge about how geomorphic features are modified in consequence of endogenous and exogenous processes. These numerical models termed as Surface Processes Models (SPMs, see Beaumont et al. (2000) for a recent overview) were successful in predicting how the tectonic activity, fluvial erosion and landslides interact to reshape the actual surface. However, these models have a restricted validity in the Eastern Alps, mainly because of the glaciation (Székely, 2001). In this paper we evaluate the present surface as it is and DEM derivatives are compared to independent geological data. Therefore, the modelling aspect of the surface evolution is not discussed in detail, only the observation is mentioned that the wet-based glaciers can by far outpace the fluvial networks in erosivity (e.g. Whipple et al., 1999). This is the case in the Eastern Alps (Székely, 2001).

On the other hand, the recent (Holocene) surface evolution started to reshape the landscape after the deglaciation. Recently Kamelger and Hinderer (1999) and Székely et al. (1999) proposed similar approaches to relate denudation processes to the ruggedness of topography. This assumption of coupling between denudation and ruggedness is feasible, because in Alpine climatic conditions and in areas with Alpine 
relief erosional processes concentrate on the valley slopes in the form of debris and rock fall and debris flow with some snow avalanche influence (Becht, 1995). Fluvial erosion plays a role in the removal and transport of the loose sediments accumulated at the foot of the slopes. The denudation rates at the peaks in Alpine environment are negligible, especially for flat top peaks (Small et al., 1997). Thus the degradation of the peaks is a result of the erosion of their slopes. This points out the importance of the steepness of the slopes: the denudation rate is strongly coupled with the surface ruggedness.

We have tested several descriptive parameters to evaluate the variation of the surface ruggedness. Classic parameters like standard deviation of the elevation are found to be somewhat biassed (Székely, 2001) by the oblique elevation distribution of the tectonic units (Frisch et al., 2000b; Székely, 2001), therefore higher order parameters found to be less affected by this obliquity are introduced. A short discussion on the topic is included in Appendix A, for further details the reader is referred to Székely (2001).

\subsection{Results of standard deviation calculations}

Standard deviation images (e.g. Székely, 2001) have been computed with several window sizes ranging from $1500 \mathrm{~m}$ up to $25.5 \mathrm{~km}$ in order to evaluate general trends and differences between tectonic units. The general behaviour is what can be expected from the theory: in the smoother areas the increase of the window size has smaller effect than in the case of the more rugged regions with deeply incised valleys (Székely, 2001). To summarize the results and to detect possibly existing domains, classifications have been carried out using the standard deviation images computed with different window sizes as multichannel data set. Both supervised (maximum likelihood) and unsupervised (ISOCLASS) classification resulted in mixed cluster patterns: the only obvious regions forming homogeneous areas are the extra-Alpine unfolded Molasse zone in the north and the Po plain in the south. These areas can also be outlined by simple techniques like histogram slicing. Areas within the Eastern Alps generally provide a mixture of several clusters. Some distinct sets of clusters form spatially more or less homogeneous regions (Fig. 4) in the unsupervised image.

The supervised classification resulted in a spatially slightly more coherent pattern: the tectonic units are represented by a mixture of two or three clusters of the corresponding training areas (Fig. 5): a typically high and rugged, a moderately elevated and less rugged and a transitional zone is observable besides the previously mentioned clusters of the Po plain and the Molasse zone. All these zones can be related to distinct tectonic units, though the coverages contain mixtures of units, which are quite different from the geological point of view (Fig. 6).

One important result of the standard deviation calculations should be that, e.g. Ötztal area and Niedere Tauern are similar to Hohe Tauern despite they are different tectonic units with very different lithologies.

\subsection{A ruggedness parameter of fourth order}

The obliquity of the elevation distributions of tectonic units (Frisch et al., 2000b) and the results of the classifications led us to find more sophisticated parameters which can define regions correlated with the boundaries of geological units.

One of several attempts was found to be useful: the pattern of a fourth order parameter denoted as $s_{z}$, the difference between the fourth central moment and the square of variance showed remarkable similarity to the geological setting (for the derivation of this parameter see Appendix B). Although the resulting image has low dynamic range, it can distinguish several areas found to be similar in the standard deviation derived images. The $s_{z}$-value images are less affected by the window size, though the problem persists.

The results are presented here in a sophisticated way. The image (Fig. 6) has been created using the hue-saturationintensity (HSI, also known as hue-saturation-value, HSV) colour model (see explanation for HSI, e.g. Mather (1987)). The intensity channel is a shaded version of the original DEM to provide spatial overview. The saturation channel is formed by an $s_{z}$-value image computed for a window size of 51 pixels $(5.1 \mathrm{~km})$. The hue channel is the same with 101 pixel $(10.1 \mathrm{~km})$ window size. A linear histogram stretch has been applied to the latter to enhance the contrast.

In Fig. 6 there are remarkable features: coloured areas with high relief like the Ötztal Alps or the Tauern Window clearly separate from greyish shaded zones like the Gurktal Alps or the most part of the Northern Calcareous Alps (NCA). There are exceptions concerning the latter region: high altitude plateaus (Dachstein, Hochkönig) with very steep margins which also involve high $s_{z}$-values.

Frisch et al. (2000b) have separated five geomorphic regions based on geological and geomorphic considerations. As compared to this subdivision, the $s_{z}$-value map separates two type groups of them (rugged vs. smooth/rounded), but performs poorly in the separation of flat, slightly tilted, elevated karstic plateaus (Dachstein) from the rugged morphology with deeply incised valleys (Ötztal, Tauern Window). This is because this method is only sensitive to the elevation distribution and there is not any spatial information about the relative positions of the different elevation values: the very same elevation data set with different spatial distribution will obviously result in the same $s_{z}$-value. (This is true for any spatially unrelated statistic parameter, too.) This points out the necessity of a method which uses also the spatial context of the data set.

\subsection{Evaluation of the local slope histogram}

One of the most widely used DEM-derivative, which also contains spatial relationship is the slope angle. Although it only gives information about the neighbouring pixels, it is directly related to the surface ruggedness: the more rugged the surface, the larger the slope angles.

On the other hand, the ruggedness-slope relation is not true on a pixel-by-pixel basis, because there may be pixels 


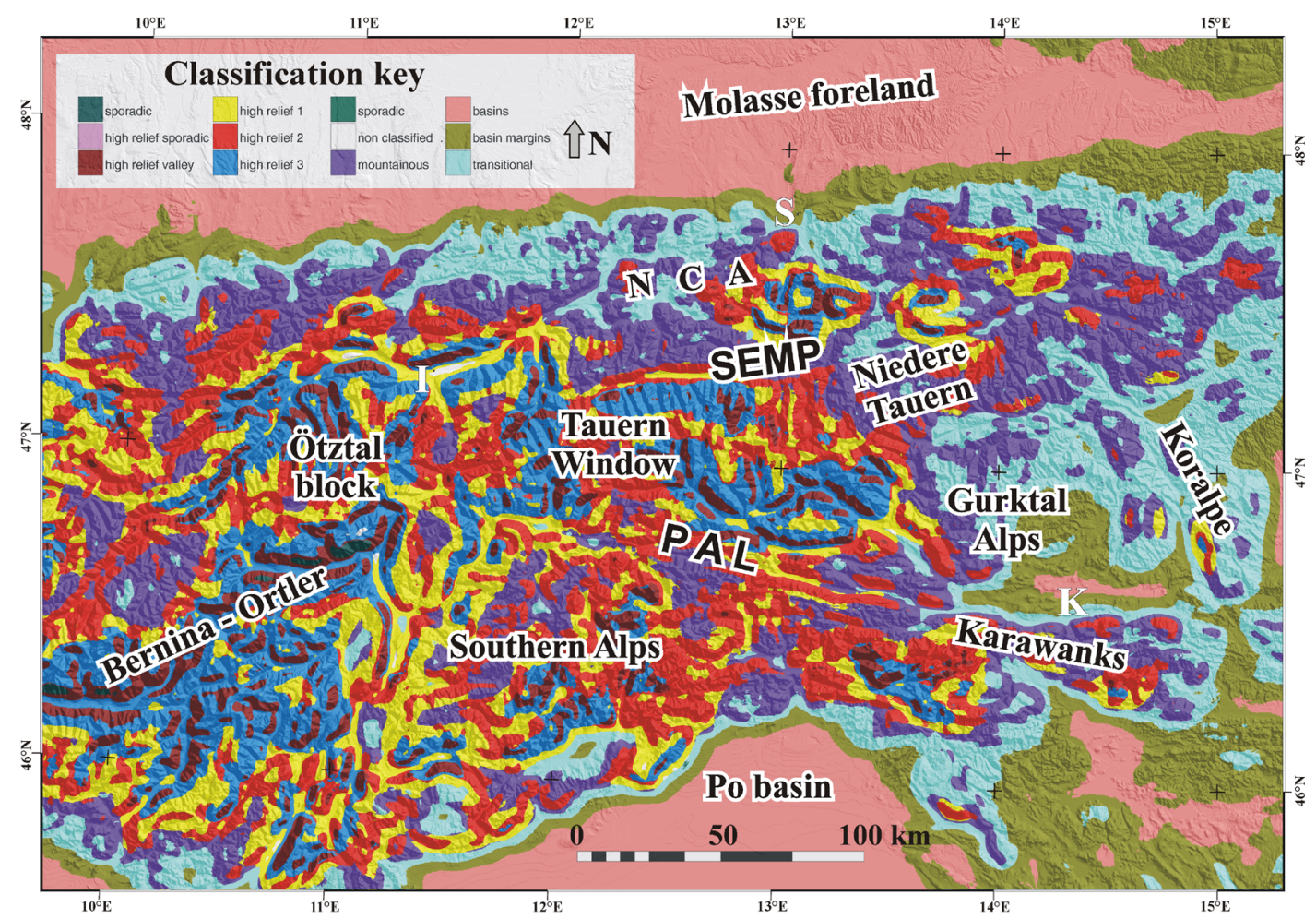

Fig. 4. Results of ISOCLASS unsupervised classification performed on a 4-channel data set. Each channel of this data set was computed from standard deviations of height values in a window; the window size was 17, 31, 63 and 127 pixels, respectively. See explanation in the text. K: Klagenfurt, S: Salzburg, I: Innsbruck. For further abbreviations see Figs. 1 and 2.

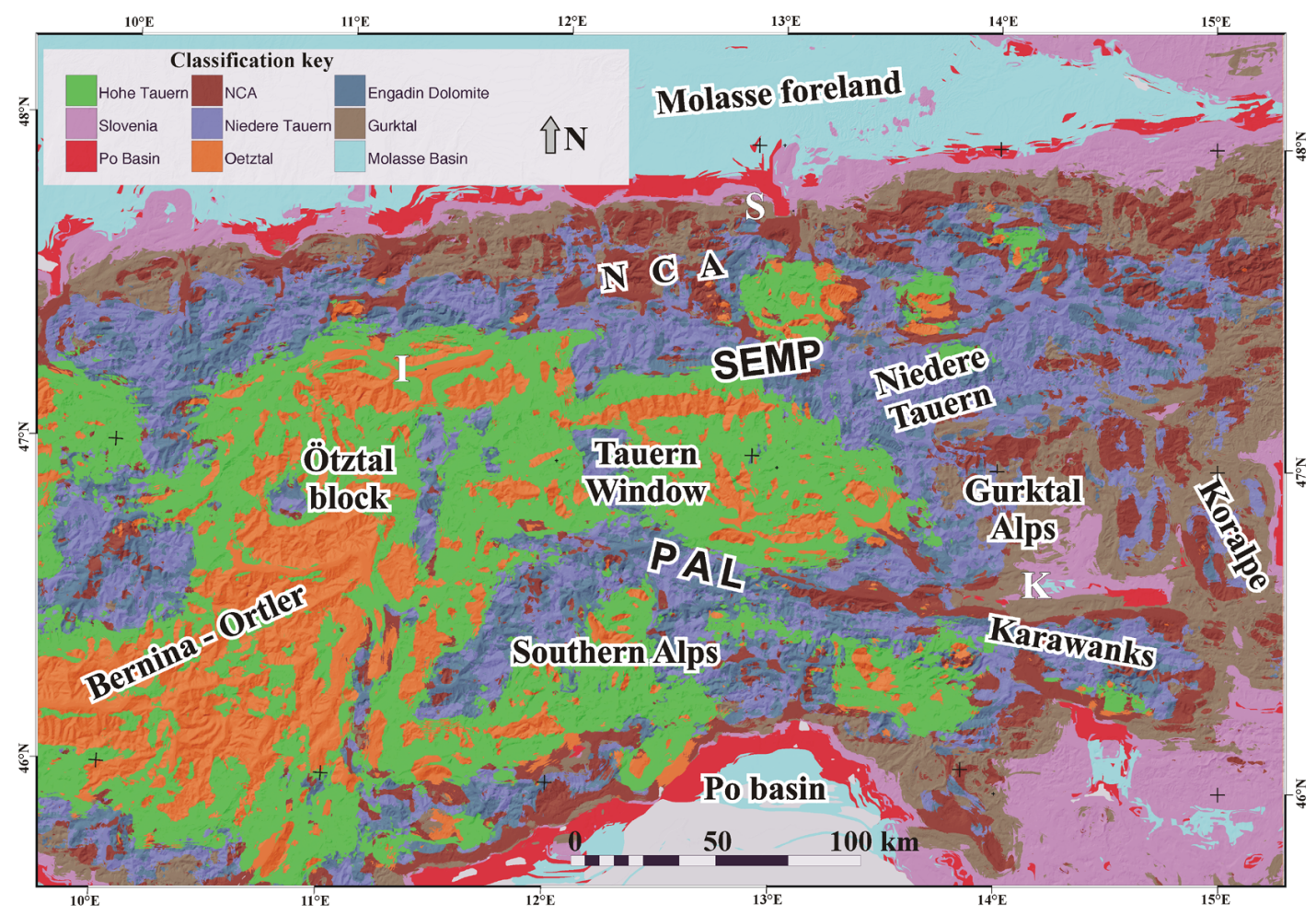

Fig. 5. Results of maximum likelihood supervised classification performed on the data set used in Fig. 4 . The training areas have been selected in the Ötztal Alps, Tauern Window, Gurktal Alps, NCA, Central Slovenia, Molasse foreland and Po basin. For localities see Fig. 4. 


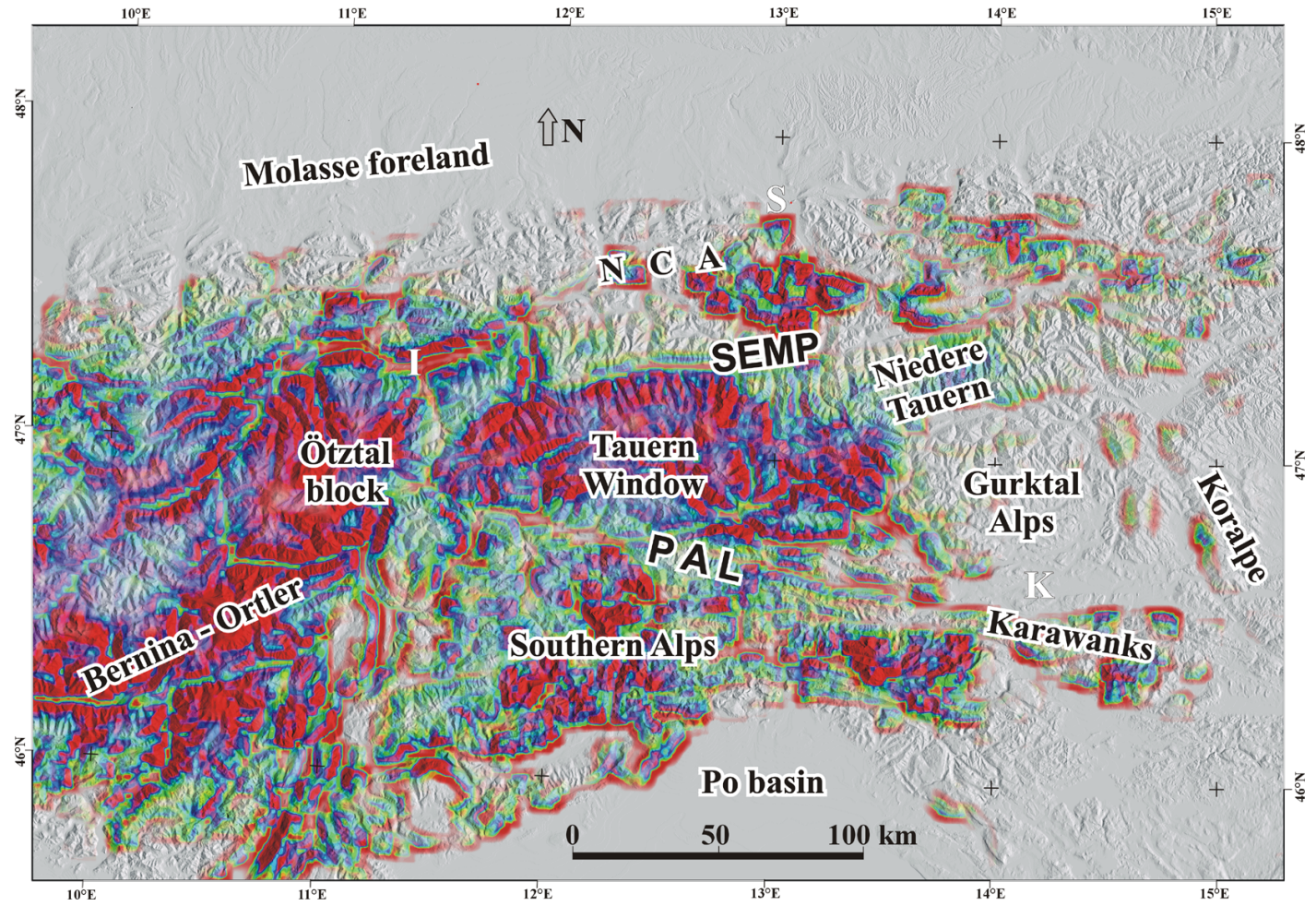

Fig. 6. HSI (hue-saturation-intensity) image composed from shaded DEM data (intensity channel), a fourth order DEM-derivative, the $s_{z}$ value computed for a window size of $5.1 \mathrm{~km}$ (saturation channel) and $10.1 \mathrm{~km}$ (hue channel). See explanation in the text, for the derivation of $s_{z}$ consult Appendix B. For localities see Fig. 4.

(e.g. in a valley bottom) where the slope angle is low, though the pixel itself belongs to a rugged area. From these considerations it is clear that for the slope distribution a windowed technique should be used to evaluate the local slope histogram for each individual area.

To achieve good resolution of the variations in the slope distribution, slope histograms have been calculated along a $5 \mathrm{~km}$ grid. Because of possible quantization errors (cf. DEM resolution), the slope histogram was chosen with a five-degree resolution. It also should be emphasized, that the slope angles are underestimated as compared to the real ones because of the horizontal and vertical resolution of the original DEM data set.

Eleven slope intervals have been defined $\left(0-5^{\circ}, 5-10^{\circ}, \ldots\right.$, $45-50^{\circ}$ and $>50^{\circ}$ ). The shape of the window was rectangular with a size of $10 \mathrm{~km}$. The number of resulting points is almost 6000 ensuring good quality statistics.

The resulting data set has been treated as an 11-channel image (where the individual channels are defined by the intervals described above), and this multiband image has been clustered by ISOCLASS classification technique. The resulting image is shown in Fig. 7. It may be emphasized that the individual colours here represent respective clusters only, the colours themselves have no specific meaning.

The cluster center values of the of the individual clusters are presented in Table 1. The most important feature of the spatial distribution of the slope clusters is the striking correlation of the cluster boundaries with that of the tectonic units. The outlines of the Alpine front (pale grey; cluster 10 and the Bohemian massif (medium grey; cluster 8 are well visible as in all derivatives of the DEM. The delineation of the Po plain (cluster 10) and the small part of the Pannonian (Styrian) basin covered by the DEM is also obvious. More importantly, small but significant features like the Tamsweg and Fohnsdorf basin and the Dachstein plateau are outlined by falling into a different cluster then their neighbouring regions. Major valleys (Inn, Adige, Möll and partly Salzach valleys) form a separate cluster (cluster 5 in Table 1). The complex tectonic surroundings of the Sava line and the Slovenian Tertiary Basin is also represented as different clusters in the map.

The cluster 1 painted in dark blue in Fig. 7 (see details for all clusters in Table 1) covers the whole Hohe Tauern and Niedere Tauern, the Ötztal block, large parts of the westernmost NCA west of the Inn valley, the Engadine Window and the Adamello. Some parts of the southwestern Southern Alps, the Carnic and Julian Alps fall into this cluster, too. Small patches appear in the eastern and central parts of the NCA.

This cluster is characterized by a relatively flat slope distribution (Table 1 ), the mode falls into the $25-30^{\circ}$ category. Steep slopes $\left(>45^{\circ}\right)$ are also represented in relatively high proportion. It covers the area which is known having "rugged" surface. The low angle categories are only weakly represented (valley bottoms). 


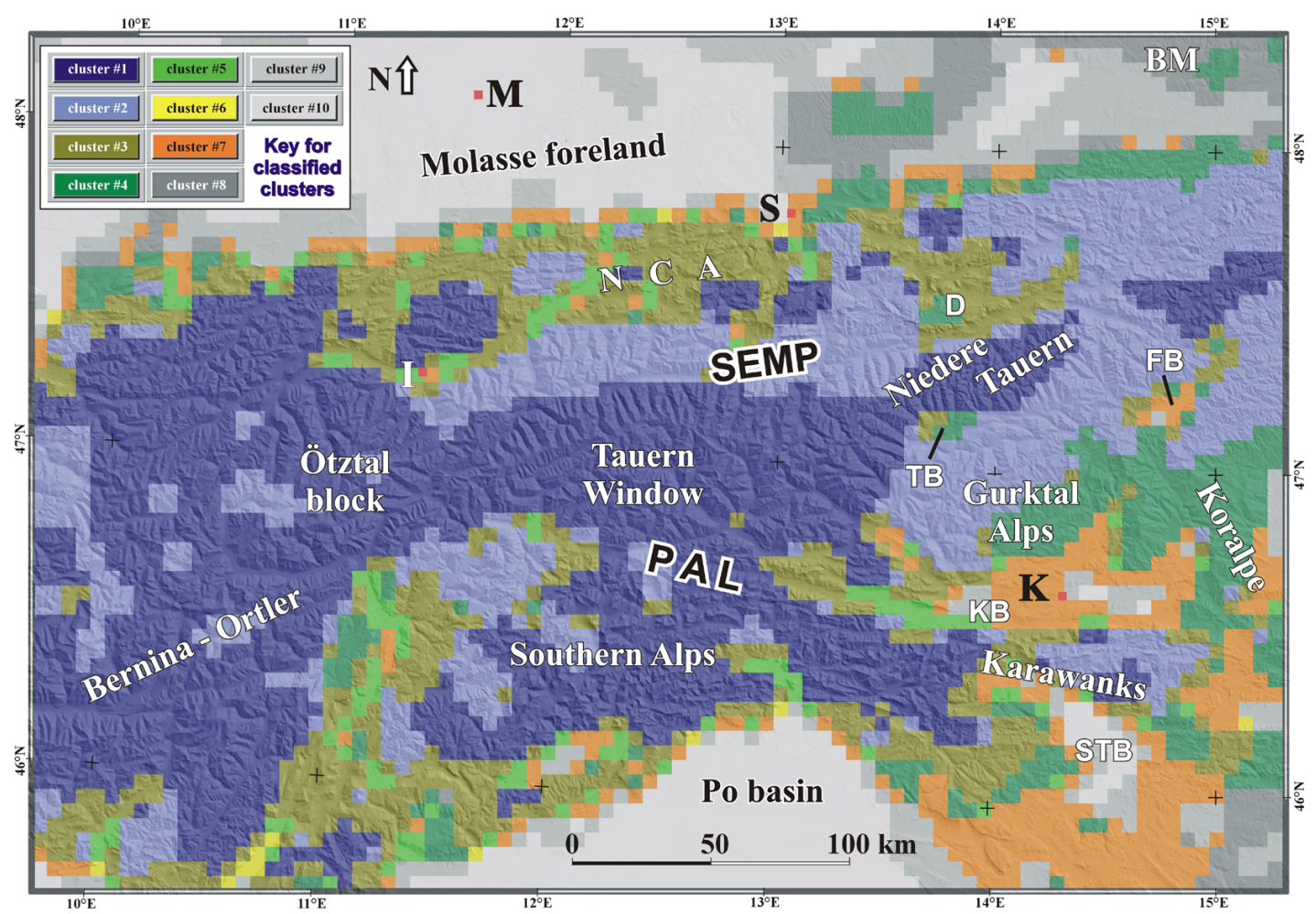

Fig. 7. Results of ISOCLASS unsupervised classification performed on an 11-channel data set. Each channel data represent the percentage of given steepness category $\left(0-5^{\circ}, 5-10^{\circ}, \ldots,>50^{\circ}\right)$ of this data set as computed from the local slope angle histogram of a $5 \mathrm{~km}$ wide window. See further explanation in the text, cf. Table 1. For localities see Fig. 4. BM: Bohemian massif.

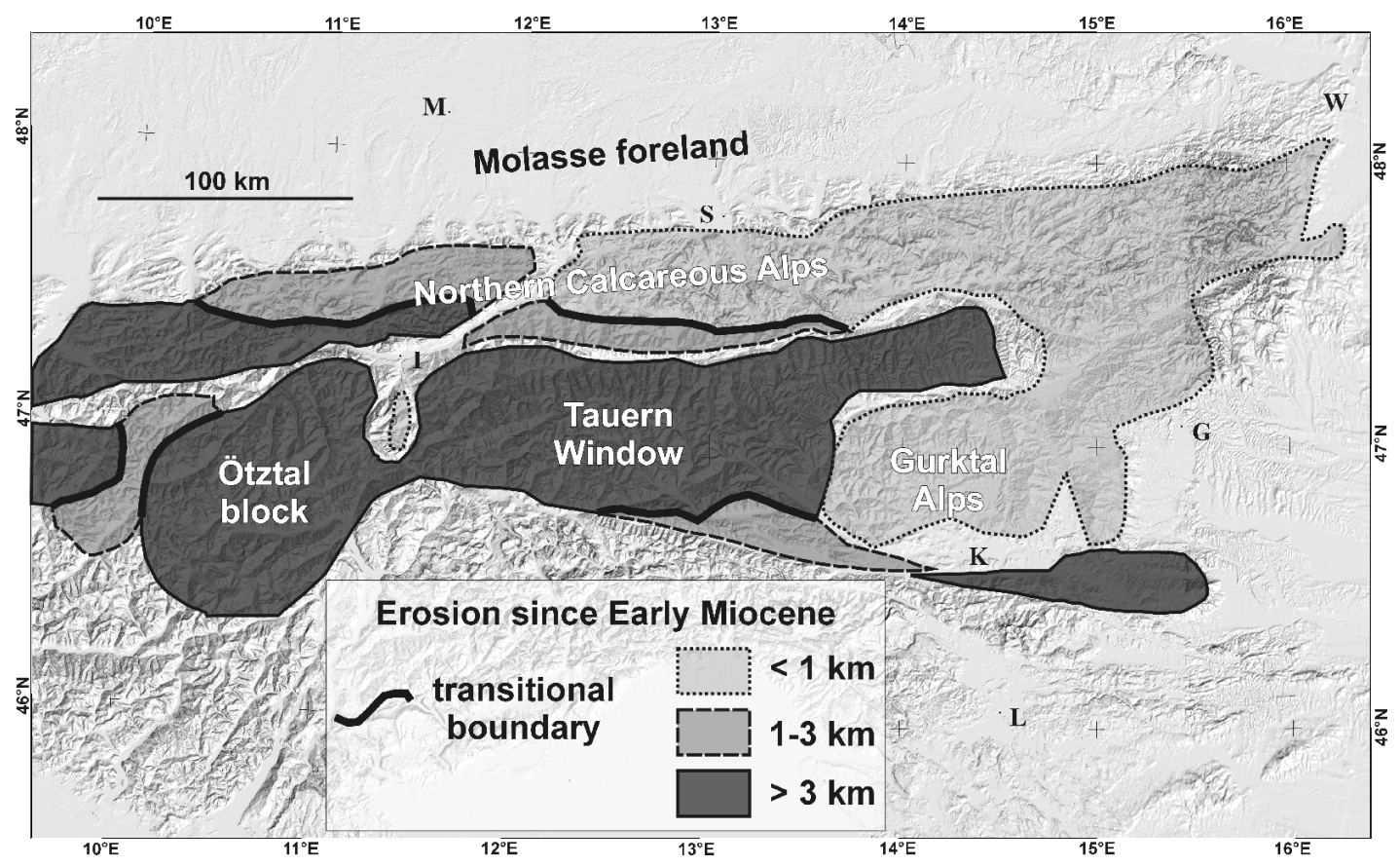

Fig. 8. Erosion thickness values in the Eastern Alps since Early Miocene calculated from apatite fission track measurements. (Data are based on results of Staufenberg, 1987; Hejl and Wagner, 1989; Fügenschuh et al., 1997; Hej1, 1997; Dunkl et al., 1998; Elias, 1998; Sachsenhofer et al., 1998; Stöckhert et al., 1999; Reinecker, 2000; and Dunkl (unpublished)). Bold lines represent transitional boundaries. M: Munich, S: Salzburg, I: Innsbruck, K: Klagenfurt, G: Graz, L: Ljubljana, W: Vienna. 
The medium blue cluster (cluster 2 in Table 1; Fig. 7) covers the Greywacke zone (note the almost perfect outline), most of the eastern NCA, Gurktal Alps and, in part, the Karawanks. The cluster contains areas where there are steep slopes as well but less frequently than in the previous cluster. The mode is in category $20-25^{\circ}$ which also shows the slight decrease of typical steepness. The proportion of slope angles in the range of $10-20^{\circ}$ is roughly twice as much as in the previous cluster.

Cluster 3 (Table 1; khaki in Fig. 7) typically appears in the Central NCA and in the southern part of the Southern Alps. It covers areas where slightly tilted plateaus as well as steep walls are present. This is reflected in its bimodal distribution: while the mode is in the $0-5^{\circ}$ category, almost the same proportion of points fall into the $10-15^{\circ}$ and $15-$ $20^{\circ}$ categories. On the other hand this cluster has the second highest proportion of slopes steeper than $35^{\circ}$.

The cluster 4 (Table 1; depicted in green in Fig. 7) consists of a variety of tectonic units which can be characterized by low local relief. The small patch of the Dachstein plateau, a part of the Tamsweg basin, and the Koralpe, Saualpe region may serve as examples. Surprisingly on the northern Alpine front there is a few-pixel-wide strip of this cluster: its $\mathrm{N}$ $\mathrm{S}$ extent correlates to the geographic position of the Flysch zone, it also can be a simple transition zone, however. The mode is in the $10-15^{\circ}$ category.

The orange cluster (cluster 7 in Table 1; Fig. 7) is also a mixture of units: north from the NCA there is an almost continuous strip which perhaps correlates partly with the subalpine molasse. (It can also be another transition zone, since it appears at the margin of the Po plain, too.) The main part of this cluster is situated in the Klagenfurt basin and the northern Dinarides. This cluster is characterized by low angle slopes with practically no steep slopes. The mode also reflects this property: it is in the first category, and almost $50 \%$ of the slopes belong here.

There is also a tiny cluster 6 (in Table 1) painted in yellow (Fig. 7) representing the lakes like Lake Constance, Lake Garda, Chiemsee and their surroundings. They should be absolutely flat, but because of the resolution some non-flat pixels are also included. That is the reason why this cluster is different from the cluster 10 representing the Po plain.

It is important to emphasize that all cluster patterns presented in this section are purely derived from the DEM data set without any further geological or geomorphic input, in other words the detected patterns are therefore inherent features of the actual surface. (In the case of the supervised classification (Sect. 4.2; Fig. 5) training areas have been selected, the outline of these training areas can be treated as external geological information.)

\section{Discussion}

In the previous sections we have collected and evaluated several sorts of data to be able to answer the question whether the actual surface pattern of the Eastern Alps is coupled with endogenous processes. Since the previously discussed data sets allow only inference on the ongoing or short-term behaviour, some data are needed to characterize the long-term processes as well. We use exhumation values derived from fission track data for this purpose (see below).

As can be seen from the previous evaluation of the ruggedness-related numerical results, there are regions which are found to be similar from the point of view of the spatial and statistical distribution of the DEM-derivatives, though the regions themselves are highly different with respect to their lithology and tectonic history. This may lead to the conclusion that the morphology is determined by exogenous processes and that climate controls the properties of the surface.

This assumption is only partially true. Of course, the climate itself plays an important role in controlling the denudation processes of the Alps (e.g. Florineth and Schlüchter, 1998; Hinderer, 1999). On the other hand, the vertical and horizontal movements due to active tectonics have to be taken into account. If the recent and active endogenous processes are not related to the characteristics of the surface, one may conclude that the present state is transitional and the processes are about to balance or change this pattern. If, on the contrary, the pattern is similar then a possible coupling may be assumed.

There is a process which is obviously faster than geological response can be: the deglaciation of the Alps happened instantaneously in terms of the geological timescale. The melting of the glaciers had a prompt effect on the surface: the increased fluvial erosion eroded or at least transported more sediments already accumulated by the glaciers during a short period of time (Hinderer, 1999). The question arises whether this process is balanced in some way or not, and, if not, whether the isostatic rebound is separable from the general uplift trend.

The outlines of the maximum vertical uplift zone fairly correlates with the boundary of the glaciers mapped by van Husen (1987). The isoline of $-0.2 \mathrm{~mm} / \mathrm{a}$ (relative to Horn) follows the boundary of the conterminous Last Glacial Maximum (LGM) ice body with an accuracy of ca. $20 \mathrm{~km}$ (Fig. 3) if we take into account the value of the typical measuring error of $\pm 0.3 \mathrm{~mm} / \mathrm{a}$. This suggests that a considerable proportion of the measurable uplift is coming from the isostatic rebound of deglaciation. On the other hand, Steinhauser and Höggerl (1988) and Meurers (1992) also found a significant correlation between recent vertical movements and Bouguer anomalies, but they note that the area of the Eastern Alps is grossly isostatically compensated, therefore the Alpine uplift is not guided by the mechanism of isostasy but rather by geodynamic forces due to plate convergence between $\mathrm{Eu}-$ rope and Adria. Interestingly, a similar conclusion has been drawn by Sharma (1984) concerning the isostatic rebound 
Table 1. Slope angle distribution of the centers of the clusters depicted in Fig. 7 (see respective colours in the first column.) Categories are 5-degree-intervals, the mode is indicated with bold numbers

\begin{tabular}{|c|c|c|c|c|c|c|c|c|c|c|c|}
\hline $\begin{array}{l}\text { Cluster } \\
\text { number, } \\
\text { colour and } \\
\text { name }\end{array}$ & $0-5^{\circ}$ & $5-10^{\circ}$ & $10-15^{\circ}$ & $15-20^{\circ}$ & $20-25^{\circ}$ & $25-30^{\circ}$ & $30-35^{\circ}$ & $35-40^{\circ}$ & $40-45^{\circ}$ & $45-50^{\circ}$ & $>50^{\circ}$ \\
\hline $\begin{array}{l}1 \text { dark blue } \\
\text { Ötztal Mts., } \\
\text { Niedere and } \\
\text { Hohe Tauern }\end{array}$ & $6.02 \%$ & $5.96 \%$ & $8.61 \%$ & $12.31 \%$ & $17.25 \%$ & $18.96 \%$ & $15.05 \%$ & $9.71 \%$ & $4.34 \%$ & $1.39 \%$ & $0.38 \%$ \\
\hline $\begin{array}{l}2 \text { medium blue } \\
\text { NCA, } \\
\text { Gurktal Alps }\end{array}$ & $6.54 \%$ & $8.89 \%$ & $15.12 \%$ & $20.01 \%$ & $21.69 \%$ & $15.88 \%$ & $7.61 \%$ & $3.05 \%$ & $0.93 \%$ & $0.23 \%$ & 0.06 \\
\hline $\begin{array}{l}3 \text { khaki } \\
\quad \text { Central NCA }\end{array}$ & $17.32 \%$ & $13.55 \%$ & $15.30 \%$ & $15.12 \%$ & $14.66 \%$ & $11.23 \%$ & $6.71 \%$ & $3.83 \%$ & $1.60 \%$ & $0.53 \%$ & $0.16 \%$ \\
\hline $\begin{array}{l}4 \text { green } \\
\text { Flysch zone, } \\
\text { Saualpen }\end{array}$ & $20.62 \%$ & $23.95 \%$ & $25.42 \%$ & $16.10 \%$ & $8.48 \%$ & $3.51 \%$ & $1.22 \%$ & $0.47 \%$ & $0.16 \%$ & $0.05 \%$ & $0.01 \%$ \\
\hline $\begin{array}{l}5 \text { light green } \\
\text { Inn valley, } \\
\text { Adige valley }\end{array}$ & $36.21 \%$ & $18.45 \%$ & $12.53 \%$ & $9.35 \%$ & $8.35 \%$ & $6.55 \%$ & $4.30 \%$ & $2.61 \%$ & $1.16 \%$ & $0.38 \%$ & $0.12 \%$ \\
\hline $\begin{array}{l}6 \text { yellow } \\
\text { Lakes and } \\
\text { surroundings }\end{array}$ & $84.00 \%$ & $7.75 \%$ & $1.85 \%$ & $1.51 \%$ & $1.60 \%$ & $1.38 \%$ & $0.93 \%$ & $0.57 \%$ & $0.28 \%$ & $0.10 \%$ & $0.03 \%$ \\
\hline $\begin{array}{l}7 \text { orange } \\
\text { Klagenfurt } \\
\text { basin and } \\
\text { Dinarides }\end{array}$ & $47.48 \%$ & $21.59 \%$ & $14.16 \%$ & $8.06 \%$ & $4.89 \%$ & $2.32 \%$ & $0.94 \%$ & $0.39 \%$ & $0.12 \%$ & $0.04 \%$ & $0.01 \%$ \\
\hline $\begin{array}{l}8 \text { dark grey } \\
\text { Bohemian } \\
\text { massif }\end{array}$ & $41.88 \%$ & $37.55 \%$ & $15.02 \%$ & $4.03 \%$ & $1.17 \%$ & $0.28 \%$ & $0.06 \%$ & $0.02 \%$ & $0.00 \%$ & $0.00 \%$ & $0.00 \%$ \\
\hline $\begin{array}{l}9 \text { medium grey } \\
\text { transitional } \\
\text { cluster }\end{array}$ & $71.91 \%$ & $20.93 \%$ & $4.52 \%$ & $1.48 \%$ & $0.70 \%$ & $0.29 \%$ & $0.10 \%$ & $0.04 \%$ & $0.01 \%$ & $0.00 \%$ & $0.00 \%$ \\
\hline $\begin{array}{l}10 \text { light grey } \\
\text { Molasse } \\
\text { zone, } \\
\text { Po plain }\end{array}$ & $92.73 \%$ & $6.65 \%$ & $0.43 \%$ & $0.10 \%$ & $0.05 \%$ & $0.02 \%$ & $0.01 \%$ & $0.00 \%$ & $0.00 \%$ & $0.00 \%$ & $0.00 \%$ \\
\hline
\end{tabular}

of Fennoscandia, where uplift rate exceeds $8 \mathrm{~mm} / \mathrm{a}$ and the uplift pattern matches that of the thickness of the LGM ice. However, the area is tectonically rather passive as compared to the Alps.

The isostatic anomaly map of Austria (Wagini et al., 1987) outlines the Tauern Window and the part of Molasse zone north of the window as negative anomalies, while the Gurktal Alps and a part of the Bohemian massif form considerable positive anomalies. This is more or less congruent with the spatial distribution of the vertical movements. We interpret the correlation of isostatic anomalies and uplift so that vertical movements are fundamentally driven by isostasy.

The Bohemian massif extends at least $50 \mathrm{~km}$ southwards beneath the Alpine nappe complex (Wessely, 1987). Meso- zoic extensional tectonics weakened the southern margin of the Bohemian massif, which led to an easier deformation of the crust beneath the advancing Alpine nappe stack. The Bohemian massif as a whole acted as a stable block of continental crust, which came in collision with the Austroalpine basement causing increased seismicity near its tip.

According to GPS measurements (Van Mierlo et al., 1997) dextral strike slip movement can be proven along the Periadriatic lineament which fits to a model of eastward extruding crustal wedges between the sinistral Mur-Mürz-LeithaLittle Carpathian fault zone and the Periadriatic lineament.

Despite the considerable effort made to convert the relative vertical motion rates to "absolute" ones, our attempt was not successful. It is quite clear from the available data 
(Gubler et al., 1992; Joó, 1992; Vyskočil, 1990, 1994) that the reference point (Horn) in the Bohemian massif is uplifting together with the whole tectonic unit. This also can be proven by the fact that the Danube is actually incising antecedently some 200-250 m into the Bohemian massif in two distinct water gaps. The "absolute" motion rate maps cited above show uplift for the Bohemian massif. The exact uplift rate which should be used as a correction value, however, ranges between $0.2-0.5 \mathrm{~mm} / \mathrm{a}$. In addition, opposite trends are found in these maps along the national boundaries. This difference may exceed $0.2 \mathrm{~mm} / \mathrm{a}$, a value too high to be neglected in this region. These findings led us to use the relative movements as they are in order to work with a more or less homogeneous data set and to avoid possible further bias effects.

As shown in the introduction, the drainage pattern is largely E-W oriented as a consequence of the Miocene lateral extrusion tectonics (Frisch et al., 1998). From the actual lateral motions presented above, it is clear that this strike-slip mode faulting, though discontinuous since Middle Miocene times, at least in part is an ongoing process. The other factor forming the actual morphology is uplift which is found to affect the whole area. Some regions which can be characterized by rugged surface have considerably higher uplift rate (in relative sense) than the average of the surroundings. Since this currently higher uplift may be due to the isostatic rebound from glaciation, which seems to be inseparable from the general uplift trend in the light of the available data and models, it is also important to know whether this is a shortterm process or can be extrapolated in time and space back to Neogene times. To check this, we compare the roughness pattern (Fig. 7) to the spatial distribution of exhumation thickness of the Eastern Alps (Fig. 8) computed from a compilation of apatite fission track data (Staufenberg, 1987; Hejl and Wagner 1989; Fügenschuh et al., 1997; Hejl, 1997; Dunkl et al., 1998; Elias, 1998; Sachsenhofer et al., 1998; Stöckhert et al., 1999; Reinecker, 2000; and Dunkl (unpublished)).

Comparing the differential exhumation pattern to the spatial distribution of ruggedness-related clusters computed from the present surface (Fig. 7), the striking similarity is obvious. Cluster 1 (Table 1) highly correlates with the area which suffered exhumation $\geq 3 \mathrm{~km}$ with minor exceptions. Cluster 2 can be largely correlated to areas of exhumation of $1-3 \mathrm{~km}$, and the spatial distribution of cluster 3 is very similar to that of the zones of less than $1 \mathrm{~km}$ exhumation. The area of the Southern Alps is not considered here. It is important to note that these data sets are independent, and both the individual exhumation and ruggedness zones cover areas of different lithologies. Thus, we conclude that the ruggedness of the present surface is highly determined by the uplift: rugged surface is a consequence of high uplift rates and these correlate with large exhumation rates. Smooth, less incised surface coincides with less exhumation and low uplift rates in the study area. Although the isostatic rebound of the deglaciation may represent a considerable part of the recently measurable uplift, this is a secondary effect of the continuous exhumation of the formerly glaciated area: besides the appropriate climatic conditions glaciers could form there because of the high average elevation as a consequence of the uplift, thus, the isostatic rebound of the deglaciation is a sort of a "delayed" uplift.

This isostatic rebound appears to represent a considerable part of the recently measurable uplift. Its value is approximately one third of the average thickness of the LGM ice thickness, i.e. a few hundred meters. This potential rebound is partly compensated elastically during the process of ice melting, and partly ductilely by mantle flow within several $10 \mathrm{ka}$ (Gudmundsson, 1994) under decreasing rates. As compared to the recent uplift rate of Fennoscandia, the potential isostatic rebound of the deglaciation in the Alps is in the range of the measured uplift rate (Gudmundsson, 1994). There is, however, a long-term uplift hidden behind the isostatic effect of deglaciation, potentially driven by tectonics and erosion. The best available minimum estimate of longterm uplift on a temporal scale of over $100 \mathrm{ka}$ is the Pleistocene sediment budget of the Eastern Alps, indicating an average denudation of $0.3 \mathrm{~mm} / \mathrm{a}$ for the rugged mountain areas (Kuhlemann, 2000).

On a temporal scale of several ka denudation rates up to 3 times of this average are observed during deglaciation (Hinderer, 1999), compensated by times of much less denudation, e.g. during periods of dense vegetation cover in Holocene times. The data presented in this study show that these rugged areas generally reflect an unmature state of relief, in which denudation cannot catch up with uplift, thus, the previously hilly landscape (Frisch et al., 1998) transformed into a mountainous one.

Since there is also a gross correlation between crustal thickness and actual uplift, we argue that isostatic compensation from Paleogene crustal stacking is still a continuing process. However, continued tectonic contraction is likely to play an important role for uplift and exhumation in the course of Miocene lateral tectonic extrusion (Ratschbacher et al., 1991a; Frisch et al., 2000a). Enhanced exhumation in the Tauern window may be explained by a combination of buoyancy forces, continued tectonic contraction, and tectonic denudation of the middle crust by removal of the rigid upper crustal layer. Tectonic contraction normally cannot force deeper crustal levels to raise, because particle flow under maintenance of isostatic equilibrium must be downward except for the uppermost $1 / 6$ th or so of the crust, according to the density difference between crust and mantle (Stüwe and Barr, 1998). However, Thompson et al. (1997) showed that, in a thickened and thermally weakened crustal stack and under continuous orogenic contraction, the orogenic root, bounded downward by hard lithospheric mantle, remains in a given depth, and soft mid-crustal material therefore can vertically extrude over considerable distances. In the case of the Eastern Alps, the soft material (see modelling of Genser et al., 1996) has also the possibility of lateral escape due to the unconstrained orogenic margin to the east (Ratschbacher et al., 1991a), so that the net particle uplift rate will be only one component of the true particle motion. Considerable rock up- 
lift in the Tauern window also led to surface uplift as revealed by the sedimentary record of eroded material (Kuhlemann, 2000).

As in the case of the Tauern window, tectonic denudation of the ductile mid-crustal level played a major role during this process. Ratschbacher et al. (1991a) and Frisch et al. (1998) proposed a model in which a combination of orogenic collapse and escape of blocks of brittle upper crust are responsible for tectonic denudation. Large-scale low-angle extensional shear zones at the western and eastern boundary of the Tauern window (Behrmann, 1988; Selverstone, 1988; Genser and Neubauer, 1989), mainly active in Early to Middle Miocene times, are testimonies of the collapse process. Several causes for this tectonic event have been proposed. Ratschbacher et al. (1991b) showed that indentation of a triangular block (according to the shape of the South Alpine block) is able to explain the observed structures. Although the motion of the South Alpine block is likely to have been dextrally transpressive (Lammerer and Weger, 1998), the exact motion direction of the indenter is not critical (see Ratschbacher et al., 1991b). Due to the triangular shape of the indenter, there resulted faster eastward motion in the southern parts of the extrusion wedge than in its northern parts (Fig. 9), thus creating a predominantly sinistral wrench corridor zone with counterclockwise block rotations (Márton et al., 2000). However, the model of Genser and Neubauer (1989), which shows a pull-apart structure due to a left-handed overstep along a sinistral fault zone, cannot fully explain the situation. Neubauer et al. (1999) propose a model, which conforms with the lateral extrusion model as proposed by Ratschbacher et al. (1991a) and additionally considers a mid-crustal ramp formed by the subducted European foreland to be responsible for vertical extrusion of the Penninic contents of the Tauern window.

In summary, the uplift history of the Eastern Alps in general and the Penninic contents of the Tauern window in particular, is thought to have its roots in a complex combination of different features. The prime cause for isostatic uplift is crustal stacking. Tectonic denudation strongly facilitated vertical extrusion of soft mid-crustal material in the Penninic windows (in general), thrusting over deep-seated ramp structures may have contributed to this process. The primary cause for tectonically induced vertical extrusion is the indentation of the South Alpine block, whose triangular shape allowed to form a sinistral wrench corridor towards the east, irrespective of the exact motion direction of the indenter. The present uplift is considered to be a combination of isostatic rebound and orogenic contraction, though we feel that the isostatic forces are the dominant feature. Among these, it is an open question whether adjustment due to the thickened crust or due to rock removal by Pleistocene glaciation and ice melt at the end of the last glaciation is the dominant process.

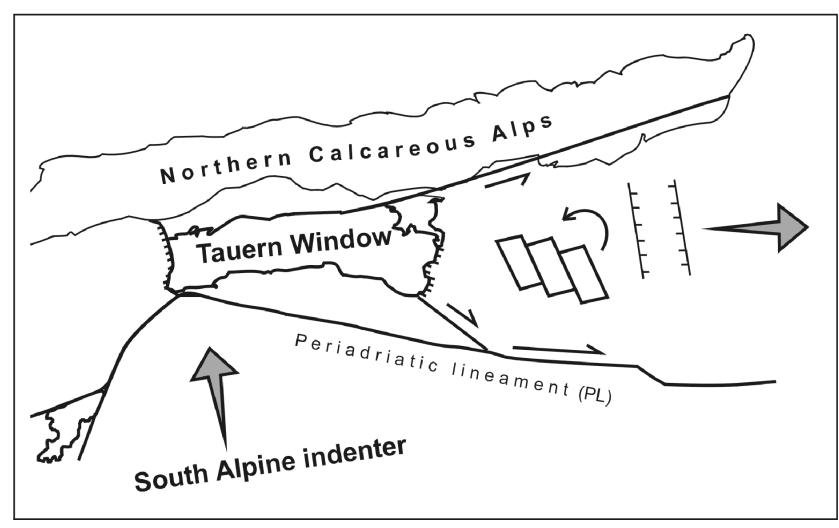

Fig. 9. Kinematic sketch of the block motions during the lateral extrusion. Note the larger displacement on the southern side of the wedge east of the Tauern Window causing CCW block rotation in the intrinsic area.

\section{Conclusions}

The following conclusions are drawn for the neotectonicgeomorphic evolution of the Eastern Alps:

1. The available rheology profiles calculated for the Eastern Alps (Genser et al., 1996; Nemes et al., 1997; Sachsenhofer et al., 1997; Lankreijer, 1998), the distribution of the earthquakes and their focal mechanism further the (sub-)recent stress measurements and calculations (Reinecker and Lenhardt, 1999; Bada et al., 2001) show that the eastern part of the Eastern Alps is a decoupling zone of the European, the Pannonian and the Adriatic stress provinces.

2. The earthquake distribution indicates that the majority of the Late Miocene faults are still active and the stress decoupling happens along the Mur-Mürz-Leitha-Little Carpathian fault system, the Lavanttal fault, the Mölltal fault, the Salzachtal-Ennstal fault, Brenner fault and Inntal fault. However, the Periadriatic line shows less seismicity.

3. Differential vertical block movements along faults are detected by precise levellings. A considerable part of vertical movements in the western part of the Eastern Alps may be due to isostatic rebound of the deglaciation. These vertical motions, however, are caused by delayed uplift postponed by the glaciation, since the glaciers formed in highly elevated, mountainous areas, and these areas have and had varying, but high uplift rates since Miocene times.

4. The integrated effect of the different exhumation of different East Alpine units is mirrored by the evaluation results of several DEM-derivates. Surface ruggedness was characterized in numerous ways to delineate geomorphic units. The domains purely derived from local slope angle distribution outline tectonic blocks with differential uplift history. 
5. The domains delineated by high fourth order DEMderivative values show good correlation to areas of young apatite fission track ages and, thus, high denudation rates in Late Tertiary times, while regions characterized by low parameter values fairly depict areas having paleosurface remnants and old FT ages.

6. Present-day uplift in the Eastern Alps is thought to be mainly driven by isostatic forces such as those caused by the differences in crustal thickness, which were strongly influenced by the Miocene large-scale extensional processes, as well as Quaternary ice-induced erosion and deglaciation. Continuous tectonic contraction may also contribute to actual uplift to a minor extent.

7. The uplift pattern grossly reflects persistency of the Miocene situation, although the driving forces have partly changed. In Miocene time, the western part of the Eastern Alps, now under general uplift, was characterized by considerable $\mathrm{N}-\mathrm{S}$ shortening and a rugged, mountainous relief. In contrast, the eastern Eastern Alps, now neutral or relatively subsiding, experienced considerable extension and crustal thinning in Miocene times resulting in low relief. Both crustal thickness (via isostasy) and tectonic forces are likely to have driven the Miocene uplift pattern.

\section{Appendix A}

Perhaps the most often used approach of surface ruggedness characterization is the computation and evaluation of the fractal dimension of the elevation data set (Turcotte, 1997 and references therein). The advantage of this method is its straightforwardness: it can take into account all variations on all scales regardless of the extent of the area or the relief. It is also advantageous, that it can characterize the mixture of all surface forming processes in one step. On the other hand, the main disadvantage of the fractal calculation is that it requires high resolution and high accuracy raw data set to get satisfying output resolution with respect to the typical size of tectonic units.

Székely (1999) pointed out that medium-elevated parts of the Eastern Alps (e.g. the Gurktal Alps) show remarkable multifractality while high areas expected to have high denudation rates are characterized by power-law (fractal) distribution with a single exponent value. This behaviour was interpreted as possible effects of glaciation and inherited landforms currently being reshaped by increased erosion. Although this multifractality is promising to be able to delineate differences between tectonic units, it also points out the necessity of a high resolution data set: the extent of the tectonic units is too small to be resolvable by this method.

Kamelger and Hinderer (1999) proposed the ASA-ratio (Active Surface Area ratio, real surface area/projected planar surface area) as a measure for the ruggedness which relates the area affected by erosion to the ruggedness in a natural way. There is a mathematical relationship between their approach and the classic slope angle oriented one, if a good resolution DEM is used. The real surface is inversely proportional to the cosine of the slope angle, thus a very good approximation for the ASA-ratio can be computed from conventional slope steepness. A possible disadvantage of the ASA-ratio may occur, when it is used for classification (clustering) purposes: the non-linear behaviour may distort the computed cluster center distances in the parameter space.

The other common way to describe the surface ruggedness is to calculate the conventional statistic properties of the elevation distribution like range (this equals to the relief in terms of geomorphology), standard deviation, sometimes skewness (and other histogram-oriented values) and, rarely, kurtosis. The main disadvantage of these methods is the inevitable definition of a local environment (in other words a radius defining the "vicinity" property) on which the whole computation is applied. In terms of image processing it is called window size, regardless of the shape of the "window", which is commonly a square or a circle. There are more "natural" approaches, when individual drainage basins are treated as "windows" (Lucazeau and Hurtrez, 1997), but this method severely constrains the applicability especially in tectonized areas.

The mandatory definition of the window size introduces a somewhat artificial parameter which also may set a sort of a scaling effect. Clearly, if the window size is so small so that the window covers only a part of a valley slope, the results will be quite different as compared to the case when one or several complete valleys are contained in one window.

These considerations prescribe constraints for the window size: on the one hand it should not exceed the typical size of a tectonic unit to avoid mixing of effects; on the other hand the window size should be large enough to cover the typical landform features of the area, like valleys, hillslopes, escarpments, steep walls, plateaus. Obviously these requirements may turn to be contradictory, especially if the typical landforms have elongated shape because of their tectonic origin.

The question of window size selection is not discussed here, the reader is referred to Székely (2001) for further theoretical considerations.

\section{Appendix B}

When the standard deviation $(s)$ is computed the squared differences between the measured value and the mean $(m)$ are averaged to get the variance $\left(s^{2}\right)$ :

$s^{2}=\frac{1}{n} \sum_{i=1}^{n}\left(x_{i}-m\right)^{2}=\frac{1}{n} \sum_{i=1}^{n} d_{i}$

where the notation $d_{i}=\left(x_{i}-m\right)^{2}$ has been introduced.

The bias is coming from the fact that $d_{i}$-values are highly and nonuniformly scattered. Therefore it is also appropriate 
to characterize the distribution of $x_{i}$-s by a value denoted as $s_{z}^{4}$ :

$s_{z}^{4}=\frac{1}{n} \sum_{i=1}^{n}\left(d_{i}-s^{2}\right)^{2}$

It is obvious that $s_{z}^{4} \geq 0$ and it is the variance of $d_{i}$-values, therefore $s_{z}^{2}$ is the standard deviation of $d_{i}$-values. If we consider the fourth root of $s_{z}^{4}, s_{z}$, it is comparable in dimension to the original $x_{i}$-values, it has a smaller range than the original distribution and it also reflects the variation in the data set which is not described by the standard deviation.

From computational point of view it is more advantageous to use the form

$s_{z}^{4}=$

$\frac{\sum x_{i}^{4}-4 m \sum x_{i}^{3}+8 m^{2} \sum x_{i}^{2}-4 m^{3} \sum x_{i}-\frac{\left(\sum x_{i}^{2}\right)^{2}}{n}}{n}$

instead of (2), because it is enough to compute $\sum x_{i}, \sum x_{i}^{2}$, $\sum x_{i}^{3}, \sum x_{i}^{4}$ and $n$ while scanning through the $x_{i}$ data once; after the completion of the calculation of these sums $s_{z}^{4}$ can be calculated in one step using (B3).

It may be emphasized that

$s_{z}^{4}=\frac{1}{n} \sum_{i=1}^{n}\left(x_{i}-m\right)^{4}-s^{4}=\mu_{4}-s^{4} ; \gamma_{2}=\frac{s_{z}^{4}}{s^{4}}-2$

where $\mu_{4}$ and $\gamma_{2}$ are known as fourth central moment and kurtosis, respectively.

Acknowledgements. We are grateful to G. Bada and F. Schlunegger for their review and to M. Kázmér, B. Koroknai, and D. Völker for their comments on an earlier version of the manuscript. The research work has been funded by Collaborative Research Center (SFB) 275 financed by the Deutsche Forschungsgemeinschaft. B. Sz. wishes to thank to GISkard Kft., Hungary for using some of their facilities for processing the DEM data.

\section{References}

Aric, K.: Deutung krustenseismischer und seismologischer Ergebnisse im Zusammenhang mit der Tektonik des Alpenostrandes. Sitzungsber. Österr. Akad. Wiss., math-naturwiss Kl., Abt. I, 190, 235-312, 1981.

Bada, G., Horváth, F., Cloetingh, S. A. P. L., Coblentz, D. D., and Tóth, T.: Role of topography-induced gravitational stresses in basin inversion: The case study of the Pannonian basin, Tectonics, 20, 343-363, 2001.

Beaumont, Ch., Kooi, H., and Willett, S.: Coupled tectonic-surface process models with applications to rifted margins and collisional orogens, in: Summerfield, M. A. (Ed).: Geomorphology and global tectonics, John Wiley \& Sons, Chichester, 29-55, 2000.

Becht, M.: Slope erosion processes in the Alps, in: Slaymaker, O. (Ed.): Steepland geomorphology, John Wiley, Chicester, 45-61, 1995.

Behrmann, J.: Crustal-scale extension in a convergent orogen: The Sterzing-Steinach mylonite zone in the Eastern Alps, Geodinamica Acta (Paris), 2, 63-73, 1988.
BEV (Bundesamt für Eich- und Vermessungswesen, Austria): Recent crustal movements in Austria. Map 1:2 000 000, Federal Office of Metrology and Surveying (BEV), Vienna, 1991.

Bressan, G., Snidarcig, A., and Venturini, C.: Present state of tectonic stress of the Friuli area (eastern Southern Alps), Tectonophys., 292, 211-227, 1998.

Decker, K. and Peresson, H.: Miocene to present-day tectonics of the Vienna basin transform fault: Links between the Alps and the Carpathians. CBGA XVI Congress Vienna 1998, 33-36, 1998.

Dongus, H.: Grundformen des Reliefs der Alpen, Geograph. Rundschau, 36, 388-394, 1984.

Dunkl, I. and Demény, A.: Exhumation of the Rechnitz Window at the border of the Eastern Alps and Pannonian basin during Neogene extension, Tectonophys., 272, 197-211, 1997.

Dunkl, I., Grasemann, B., and Frisch, W.: Thermal effects of exhumation of a metamorphic core complex on hanging wall synrift sediments: an example from the Rechnitz Window, Eastern Alps, Tectonophys., 297, 31-50, 1998.

Elias, J.: The thermal history of the Ötztal-Stubai complex (Tyrol, Austria/Italy) in the light of the lateral extrusion model, Tübinger Geowiss. Arb., Reihe A, 42, 172p, 1998.

Florineth, D. and Schlüchter, Ch.: Reconstructing the last glacial maximum (LGM) ice surface geometry and flowlines in the Central Swiss Alps, Eclogae geol. Helv., 91, 391-407, 1998.

Frisch, W., Kuhlemann, J., Dunkl, I., and Brügel, A.: Palinspastic reconstruction and topographic evolution of the Eastern Alps during late Tertiary extrusion, Tectonophys., 297, 1-15, 1998.

Frisch, W., Dunkl, I., and Kuhlemann, J.: Postcollisional orogenparallel large-scale extension in the Eastern Alps, Tectonophys., 327, 239-265, 2000a.

Frisch, W., Székely, B., Kuhlemann, J., and Dunkl, I.: Geomorphological evolution of the Eastern Alps in response to the Miocene tectonics, Z. Geomorph. N.F., 44, 103-138, 2000 b.

Fügenschuh, B., Seward, D., and Mancktelow, N.: Exhumation in a convergent orogen: the western Tauern window. Terra Nova, 9, 213-217, 1997.

Genser, J. and Neubauer, F.: Low angle normal faults at the eastern margin of the Tauern window (Eastern Alps). Mitt. österr. geol. Ges., 81, 233-243, 1989.

Genser, J., van Wees, J. D., Cloetingh, S. A. P.L., and Neubauer, F.: Eastern Alpine tectono-metamorphic evolution: Constraints from two-dimensional P-T-t modeling, Tectonics, 15, 584-604, 1996.

Gerner, P., Dövényi, P., Horváth, F., and Müller, B.: State of recent stress and seismotectonics in the Pannonian basin and surrounding areas, Terra Abstracts, Abst. Suppl. 1, 7, 173, 1995.

Giese, P.: Krustenstruktur der Alpen. Ein Überblick verbunden mit einigen tektonischen Betrachtungen, Berl. geowiss. Abh. Reihe A, 20, 51-80, 1980.

Grundmann, G. and Morteani, G.: The young uplift and thermal history of the Central Eastern Alps (Austria/Italy); evidence from apatite fission track ages, Jb. Geol. B.-A. Wien, 128, 197-216, 1985.

Gubler, E., Arca, S., Kakkuri, J., Zippelt, K.: Recent vertical movement data (Germany and Switzerland), in: Blundell, D.,Freeman, R., and Mueller, St. (Eds.): A continent revealed: The European Geotraverse Database, Cambridge University Press, Cambridge, 1992.

Gudmundsson, G. H.: An order-of-magnitude estimate of the current uplift-rates in Switzerland caused by the Würm Alpine deglaciation, Eclogae geol. Helv., 87, 545-557, 1994. 
Guzzetti, F. and Reichenbach, P.: Towards a definition of topographic divisions for Italy, Geomorphology, 11, 57-74, 1994.

Hejl, E.: "Cold spots" during the Cenozoic evolution of the Eastern Alps; thermochronological interpretation of apatite fission-track data, in: Neubauer, F., Cloetingh, S. A. P. L., Dinu, C., and Mocanu, V. (Eds.): Tectonics of the Alpine-Carpathian-Pannonian region; II., Tectonophys., 272, 159-173, 1997.

Hejl, E. and Wagner, G.: Apatit-Spaltspurendaten zur thermischen Geschichte der Nördlichen Kalkalpen, der Flysch- und Molassezone. Jb. Geol. B.-A. Wien, 132, 191-212, 1989.

Hinderer, M.: Late Quaternary and modern denudation of the Alps and implications for climate-controlled erosional processes, Tübinger Geowiss. Arb., Reihe A, 52, 70-71, 1999.

Höggerl, N.: Repeated levelling and vertical crustal movements; problems and results, in: Scheidegger, A. E. (Ed.): Tectonic stresses in the Alpine-Mediterranean region, Rock Mechanics Suppl., 9, 201-212, 1980.

Höggerl, N.: Höhenänderungen im nördlichen Wiener Becken, in: Steinhauser, P. and Walach, G. (Eds.): Tagungsbericht 6. Internat. Alpengravimetrie-Kolloquium, Leoben 1993, Österr. Beitr. Meteor. Geoph., 8, 161-175, 1993.

Horváth, F. and Cloetingh, S. A. P. L.: Stress-induced late-stage subsidence anomalies in the Pannonian basin, in: Cloetingh, S. A. P. L., Ben Avraham, Z., Sassi, W., and Horváth, F. (Eds.): Dynamics of extensional basins and inversion tectonics, Tectonophys., 266, 287-300, 1996.

Joó, I.: Recent vertical surface movements in the Carpathian Basin, Tectonophys., 202, 129-134, 1992.

Kamelger, A. and Hinderer, M.: Interrelationship between surface roughness and erosion processes: examples from the Swiss Alps, Tübinger Geowiss. Arb., Reihe A, 52, 160, 1999.

Kröll, A., Gnojek, I., Heinz, H., Jiříček, R., Meurers, B., Seiberl, W., Steinhauser, P., Wessely, G., and Zych, D.: Wiener Becken und angrenzende Gebiete. Geologische Themenkarte der Republik Österreich, 1:200000, Geologische Bundesanstalt, Wien, 1993.

Kuhlemann, J.: Post-collisional sediment budget of circum-Alpine basins (Central Europe), Mem. Sci. Geol. Padova, 52/1, 1-91, 2000.

Lammerer, B. and Weger, M.: Footwall uplift in an orogenic wedge: the Tauern Window in the Eastern Alps of Europe, Tectonophys., 285, 213-230, 1998.

Lankreijer, A.: Rheology and basement control on extensional basin evolution in Central and Eastern Europe: Variscan and AlpineCarpathian-Pannonian tectonics, $\mathrm{PhD}$ thesis Vrije Universiteit Amsterdam, 157p., 1998.

Lucazeau, F. and Hurtrez, J. E.: Length-scale dependence of relief along the southeastern border of Massif Central (France), Geoph. Res. Lett., 24, 1823-1826, 1997.

Mackenbach, R.: Jungtertiäre Entwässerungsrichtungen zwischen Passau und Hausruck (Oberösterreich), Sonderveröff. Geol. Inst. Univ. Köln, 55, 175 p., 1984.

Márton, E., Kuhlemann, J., Frisch, W., and Dunk1, I.: Miocene rotations in the Eastern Alps - Paleomagnetic results from intramontane basin sediments, Tectonophys., 323, 163-182, 2000.

Mather, P. M.: Computer processing of remotely-sensed images, John Wiley, Chicester, 352 p., 1987.

Meurers, B.: Untersuchungen zur Bestimmung und Analyse des Schwerefeldes im Hochgebirge am Beispiel der Ostalpen, Österr. Beitr. Meteor. Geoph., 6, 146p., 1992.

Müller, B., Zoback, M.-L., Fuchs, K., Mastin, L. G., Gregersen, S., Pavoni, N., Stephansson, O., and Ljunggren, Ch.: Regional pat- terns of tectonic stress in Europe, J. Geophys. Res. 97, $11783-$ $11803,1992$.

Nemes, F., Neubauer, F., Cloetingh, S. A. P. L., and Genser, J.: The Klagenfurt basin in the Eastern Alps: an intra-orogenic decoupled flexural basin?, Tectonophys., 282, 189-203, 1997.

Neubauer, F., Genser, J., Kurz, W., and Wang, X.: Exhumation of the Tauern Window, Eastern Alps. Phys. Chem. Earth (A), 24, 675-680, 1999.

Posgay, K., Albu, I., Mayerova, M., Nakladalova, Z., Ibrmajer, I., Blizkovsky, M., Aric, K., and Gutdeutsch, R.: Contour map of the Mohorovičić discontinuity beneath central Europe. Geofiz. Közl. 36, 7-13, 1991.

Ratschbacher, L., Frisch, W., Linzer, H.-G., and Merle, O.: Lateral extrusion in the Eastern Alps, part 2: Structural analysis, Tectonics, 10, 257-271, 1991a.

Ratschbacher, L., Merle, O., Davy, Ph., and Cobbold, P.: Lateral extrusion in the Eastern Alps, part 1: Boundary conditions and experiments scaled for gravity, Tectonics, 10, 245-256, $1991 \mathrm{~b}$.

Reinecker, J.: Stress and deformation: Miocene to present-day tectonics in the Eastern Alps, Tübinger Geowiss. Arb., Reihe A, 55, 128 p, 2000.

Reinecker, J. and Lenhardt, W. A.: Present-day stress field and deformation in eastern Austria. Int. J. Earth Sci., 88, 532-550, 1999.

Sachsenhofer, R. F., Lankreijer, A., Cloetingh, S. A.P.L., and Ebner, F.: Subsidence analysis and quantitative basin modelling in the Styrian Basin (Pannonian Basin System, Austria), Tectonophys., 272, 175-196, 1997.

Sachsenhofer, R. F., Dunkl, I., Hasenhüttl, Ch., and Jelen, B.: Miocene thermal history of the southwestern margin of the Styrian Basin: coalification and fission track data from the Pohorje/Kozjak area (Slovenia). Tectonophys., 297, 17-29, 1998.

Sakaguchi, Y.: Über die geomorphologische Entwicklung der Ostalpen. Hangforschung und Morphologie der Landoberflächen - Evolution des pentes et morphologie continentale, Z. Geopmorph. N. F., Suppl. Bd., 18, 144-155, 1973.

Selverstone, J.: Evidence for east-west crustal extension in the Eastern Alps: implications for the unroofing history of the Tauern Window, Tectonics, 7, 87-105, 1988.

Sharma, P. V.: The Fennoscandian uplift and glacial isostasy, in: Gupta, H. K. (Ed.): Lithosphere: structure, dynamics and evolution, Tectonophys., 105, 249-262, 1984.

Small, E. E., Anderson, R. S., Repka, J. L., and Finkel, R.: Erosion rates of alpine bedrock summit surfaces deduced from in situ ${ }^{10} \mathrm{Be}$ and ${ }^{26} \mathrm{Al}$, Earth Planet. Sci. Lett., 150, 413-425, 1997.

Staufenberg, H.: Apatite fission-track evidence for postmetamorphic uplift and cooling history of the eastern Tauern window and the surrounding Austroalpine (central Eastern Alps, Austria). Jb. Geol. B.-A. Wien, 130, 571-586, 1987.

Steinhauser, P. and Höggerl, N.: On the correlation between recent crustal movements and gravity anomalies in Austria, Bull. Informat. BGI, 62, 1-17, 1988.

Stöckhert, B., Brix, M. R., Kleinschrodt, R., Hurford, A. J., and Wirth, R.: Thermochronometry and microstructures of quartz a comparison with experimental flow laws and predictions on the temperature of the brittle-plastic transition. J. Struct. Geol. 21, 351-369, 1999.

Stüwe, K., and Barr, T. D.: On uplift and exhumation during convergence, Tectonics, 17, 80-88, 1998.

Székely, B.: Results of fractal dimension calculations applied on the Digital Elevation Model of the Eastern Alps. Tübinger. Geowiss. Arb., Reihe A, 52, 212, 1999. 
Székely, B., Frisch, W., Reinecker, J., Dunkl, I., and Kuhlemann, J.: Present and paleosurfaces - a multimethod approach for the Eastern Alps, Tübinger Geowiss. Arb., Reihe A, 52, 40-46, 1999.

Székely, B.: On the surface of the Eastern Alps - a DEM study. Tübinger Geowiss. Arb., Reihe A, 60, 1-157, 2001.

Tollmann, A.: Geologie von Österreich, Band 3, Deuticke, Wien, $718 \mathrm{p}, 1986$.

Thompson, A. B., Schulmann, K., and Jezek, J.: Extrusion tectonics and elevation of lower crustal metamorphic rocks in convergent orogens. Geology, 25, 491-494, 1997.

Turcotte, D. L.: Fractals and chaos in geology and geophysics, 2nd ed., Cambridge University Press, New York, 370 p., 1997.

van Husen, D.: Zur Schichtfolge und Tektonik des Jungquartärs zwischen Rechberg und Homarow-Berg und seine Beziehung zur Hebung der Karawanken. Carinthia II, 86 113-126, Klagenfurt, 1976.

van Husen, D.: Die Ostalpen in den Eiszeiten. Geologische Bundesanstalt, Wien, 24p., 1987.

van Mierlo, J., Oppen, S., and Vogel, M.: Monitoring of the Recent crustal movements in the Eastern Alps with the Global Positioning System (GPS). Tectonophys. 275, 273-283, 1997.

Vyskočyl, P. (Ed.): Map of the horizontal gradients of recent vertical crustal movements of territories of Bulgaria, Czechoslovakia, GDR, Hungary, Poland, Rumania, USSR (European part of the country), 1:2500 000, Moscow, 1990.

Vyskočyl, P. (Ed.): Map of annual velocities (regional trends) of vertical surface movements on the territory of a part of Central Europe. Manuscript, 1994.

Wagini, A., Steinhauser, P., and Meurers, B.: Isostatic residual gravity map of Austria. USGS Open-File Report, 87-402, 1987.

Ward, S. N.: Constraints on the seismotectonics of the central Mediterranean from Very Long Baseline Interferometry. Geophys. J. Int. 117, 441-452, 1994.

Whipple, K. X., Kirby, E., Brocklehurst, S. H.: Geomorphic limits to climate-induced increases in topographic relief, Nature, 402, 39-43, 1999.

Winkler-Hermaden, A.: Geologisches Kräftespiel und Landformung. Springer, Wien, 822p, 1957.

Wessely, G.: Mesozoic and Tertiary evolution of the AlpineCarpathian foreland in eastern Austria, in: Ziegler, P. A. (Ed.) Compressional intra-plate deformations in the Alpine Foreland, Tectonophys., 137 45-59, 1987.

ZAMG (Zentralanstalt für Meteorologie und Geodynamik): Austrian Earthquake Catalogue ("AEC"'). (ZAMG, Central Institute for Meteorology and Geodynamics - Department of Geophysics), Vienna, Austria, http://www.zamg.ac.at, 1999.

Zimmer, W. and Wessely, G.: Exploration results in thrust and subthrust complexes in the Alps and below the Vienna Basin in Austria, in: Wessely, G. and Liebl, W. (Eds.): Oil and gas in Alpidic thrustbelts and basins of Central and Eastern Europe, EAGE Special Publication, 5, 81-107, 1996. 